\title{
2,3-Disubstituted Thiophene-Based Organic Dyes for Solar Cells
}

\author{
K. R. Justin Thomas, ${ }^{\dagger}$ Ying-Chan Hsu, ${ }^{\dagger}$ Jiann T. Lin, ${ }^{*}, \dagger, \ddagger$ Kun-Mu Lee ${ }^{\S}$ \\ Kuo-Chuan Ho, ${ }^{*},{ }^{, / l}$ Chin-Hung Lai, ${ }^{\perp}$ Yi-Ming Cheng, ${ }^{\perp}$ and Pi-Tai Chou ${ }^{*, \perp}$ \\ Institute of Chemistry, Academia Sinica, Taipei 115, Taiwan, Department of Chemistry, National Central \\ University, Chungli 320, Taiwan, and Departments of Chemical Engineering and Chemistry and Institute \\ of Polymer Science and Engineering, National Taiwan University, Taipei 106, Taiwan
}

Received September 14, 2007. Revised Manuscript Received November 22, 2007

\begin{abstract}
New organic dyes that contain variable lengths of conjugation, featuring oligothiophene and arylamines at the 2- and 3-position, have been synthesized. These compounds are characterized by photophysical, electrochemical, and theoretical computational methods. Nanocrystalline $\mathrm{TiO}_{2}$-based dye-sensitized solar cells were fabricated using these molecules as light-harvesting sensitizers. The overall efficiencies of the sensitized cells range from 4.11 to $6.15 \%$, compared to a cis-di(thiocyanato)-bis(2,2'-bipyridyl)-4,4'dicarboxylate ruthenium(II)-sensitized device $(7.86 \%)$ fabricated and measured under similar conditions. The devices made from these compounds have higher open-circuit voltage $\left(V_{\mathrm{OC}}\right)$ compared to oligothiophene congeners with arylamines at the 2-position only. The hydrophobic segment at the 3-position appears to help retarding the charge transfer from the conduction band of $\mathrm{TiO}_{2}$ to the electrolyte, $\mathrm{I}_{3}{ }^{-}$. Supplementary studies of the transient photovoltage and electrochemical impedance are in support of retarded charge transfer of $\mathrm{TiO}_{2}\left(\mathrm{e}^{-}\right)$with both oxidized sensitizer and $\mathrm{I}_{3}{ }^{-}$. Computation on a pair of compounds with and without arylamines at 3-position indicates that the former has larger charge transfer efficiency at the electronically excited state.
\end{abstract}

\section{Introduction}

Dye-sensitized solar cells (DSSCs) based on organic and organometallic complexes have attracted considerable attention since the seminal report by Grätzel and co-workers. ${ }^{1}$ Prototype Ru complexes such as N3, N719, and the black dye have been demonstrated to show photoconversion efficiency $(\eta)$ up to $11 \%$ under AM 1.5 irradiation. $^{2}$ In view of the high cost associated with the production and purification of the ruthenium dyes, organic dyes are considered to be an alternative, as they are easily accessible. Furthermore, organic dyes normally exhibit high molar extinction coefficients surpassing those of Ru dyes $\left(\epsilon<20000 \mathrm{M}^{-1} \mathrm{~cm}^{-1}\right)$. To date, the highest photoconversion efficiency of organic dye-sensitized solar cells has exceeded $9 \%$. $^{3}$ A common design of the organic sensitizer is to link the electron donor and the electron acceptor by a conjugated spacer. Then the $\mathrm{TiO}_{2}$ surface anchoring group, such as carboxylate, phos-

* Corresponding author. E-mail: jtlin@chem.sinica.edu.tw (J.T.K.); kcho@ ntu.edu.tw (K.-C.H.); chop@ntu.edu.tw (P.-T.C).

Institute of Chemistry, Academia Sinica.

* National Central University.

$\S$ Institute of Polymer Science and Engineering, National Taiwan University.

" Department of Chemical Engineering, National Taiwan University.

${ }^{\perp}$ Department of Chemistry, National Taiwan University.

(1) (a) Nazeeruddin, M. K.; Kay, A.; Rodicio, I.; Humphry-Baker, R.; Müller, E.; Liska, P.; Vlachopoulos, N.; Grätzel, M. J. Am. Chem. Soc. 1993, 115, 6382. (b) Nazeeruddin, M. K.; Péchy, P.; Renouard T.; Zakeeruddin, S. M.; Humphry-Baker, R.; Comte, P.; Liska, P.; Cevey, L.; Costa, E.; Shklover, V.; Spiccia, L.; Deacon, G. B.; Bignozzi, C. A.; Grätzel, M. J. Am. Chem. Soc. 2001, 123, 1613.

(2) Grätzel, M. J. Photochem. Photobiol., A 2004, 168, 235.

(3) (a) Ito, S.; Zakeeruddin, S. M.; Humphrey-Baker, R.; Liska, P.; Charvet, R.; Comte, P.; Nazeeruddin, M. K.; Péchy, P.; Takata, M.; Miura, H.; Uchida, S.; Grätzel, M. Adv. Mater. 2006, 18, 1202. (b) Horiuchi, T.; Miura, H.; Sumioka, K.; Uchida, S. J. Am. Chem. Soc. 2004, 126, 12218 . phonate, or sulfonate, is integrated at the acceptor end. Light irradiation on these dipolar molecules induces intramolecular charge transfer from the donor to the acceptor, with subsequent electron injection to the $\mathrm{TiO}_{2}$ via the anchoring group. Several dipolar metal-free dyes have been reported as sensitizers in DSSCs in recent years. These include coumarin-, ${ }^{4}$ indoline-,${ }^{3}$ cyanine-,${ }^{5}$ hemicyanine-,${ }^{6}$ merocyanine-,${ }^{7}$ perylene-,${ }^{8}$ xanthene-,${ }^{9}$ triarylamine-,${ }^{10}$ oligoene-,${ }^{11}$ and thiophene-based ${ }^{12}$ dyes. An ideal sensitizer has to fulfill the following criteria: (1) it has a sufficiently high LUMO energy level for efficient electron injection into the $\mathrm{TiO}_{2}$ and a sufficiently low HOMO energy level for efficient regenera-

(4) (a) Hara, K.; Sayama, K.; Ohga, Y.; Shinpo, A.; Suga, S.; Arakawa, H. Chem. Commun. 2001, 569. (b) Hara, K.; Kurashige, M.; Dan-oh, Y.; Kasada, C.; Shinpo, A.; Suga, S.; Sayama, K.; Arakawa, H. New J. Chem. 2003, 27, 783.

(5) (a) Ehret, A.; Stuhl, L.; Spitler, M. T. J. Phys. Chem. B 2001, 105, 9960. (b) Sayama, K.; Hara, K.; Ohga, Y.; Shinpou, A.; Suga, S.; Arakawa, H. New J. Chem. 2001, 26, 200.

(6) (a) Wang, Z.-S.; Li, F.-Y.; Huang, C.-H. Chem. Commun. 2000, 2063. (b) Stathatos, E.; Lianos, P. Chem. Mater. 2001, 13, 3888. (c) Yao, Q.-H.; Meng, F.-S.; Li, F.-Y.; Tian, H.; Huang, C.-H. J. Mater. Chem. 2003, 13, 1048.

(7) (a) Khazraji, A. C.; Kotchandani, S.; Das, S.; Kamat, P. V. J. Phys. Chem.B. 1997, 103, 4693. (b) Sayama, K.; Tsukagoshi, S.; Mori, T.; Hara, K.; Ohga, Y.; Shinpou, A.; Abe, Y.; Suga, S.; Arakawa, H. Sol. Energy Mater. Sol. Cells 2003, 80, 47.

(8) (a) Ferrere, S.; Zaban, A.; Gregg, B. A. J. Phys. Chem. B 1997, 101, 4490. (b) Ferrere, S.; Gregg, B. A. New J. Chem. 2002, 26, 1155.

(9) Hara, K.; Horiguchi, T.; Kinoshita, T.; Sayama, K.; Sugihara, H.; Arakawa, H. Chem. Lett. 2000, 29, 316.

(10) Liang, M.; Wu, W.; Cai, F.; Chen, P.; Peng, B.; Chen, J.; Li, Z. J. Phys. Chem. C 2007, 111, 4465.

(11) (a) Kitamura, T.; Ikeda, M.; Shigaki, K.; Inoue, T.; Anderson, N. A.; Ai, X.; Lian, T.; Yanagida, S. Chem. Mater. 2004, 16, 1806. (b) Hara, K.; Sato, T.; Katoh, R.; Furube, A.; Yashihara, T.; Murai, M.; Kurashige, M.; Ito, S.; Shinpo, A.; Suga, S.; Arakawa, H. Adv. Funct. Mater. 2005, 15, 246. 
tion of the oxidized state; (2) it absorbs solar radiation strongly, with the absorption band in the visible region extending to near-IR; (3) it possesses enough spatial separation between the positive charge density on the dye and the electrons injected. ${ }^{13}$

We have long been interested in the development of new sensitizers for solar cell applications and have recently reported a series of efficient DSSCs using new dipolar arylamine/cyanoacrylic acid sensitizers containing thiophene unit as the spacer. ${ }^{12 \mathrm{a}, \mathrm{b}}$ Thiophene-based $\pi$-conjugated oligomers and polymers have been widely used in photovoltaic cells because of their chemical and environmental stability as well as their electronic tunability. ${ }^{14}$ Though there are some examples incorporating the thiophene ring in organic sensitizers, ${ }^{12}$ use of oligo(2,5-thiophene) is still rare. ${ }^{12 \mathrm{c}, \mathrm{g}, \mathrm{i}-\mathrm{k}} \mathrm{In}$ this study, we used oligothiophene as the spacer of dipolar sensitizer based on the following reasons: (i) thiophene can provide more effective conjugation than benzenoid moieties; ${ }^{15}$ (ii) oligothiophene has a greater tendency to be coplanar than oligo(1,4-phenylene), thus elongating the $\pi$ conjugation. In addition, one of the thiophene rings was strategically incorporated with the arylamine donor at the $\mathrm{C} 2$ and $\mathrm{C} 3$ positions (see Scheme 1), such that the delocalization of the positive charge between the $\mathrm{C} 2$ and $\mathrm{C} 3$ substituents, after electron injection, may retard back electron transfer from $\mathrm{TiO}_{2}$ to the oxidized dye. Moreover, the hydrophobic nature of the $\mathrm{C} 3$ substituent may suppress electron transfer from $\mathrm{TiO}_{2}$ to the electrolyte (i.e., dark current). To the best of our knowledge, no 2,3-disubstituted thiophene-based dipolar sensitizers have been reported.

(12) (a) Velusamy, M.; Justin Thomas, K. R.; Lin, J. T.; Hsu, Y.-C.; Ho, K.-C. Org. Lett. 2005, 7, 1899. (b) Justin Thomas, K. R.; Lin, J. T.; Hsu, Y.-C.; Ho, K.-C. Chem. Commun. 2005, 4098. (c) Hara, K.; Wang, Z.-S.; Sato, T.; Furube, A.; Katoh, R.; Sugihara, H.; Dan-oh, Y.; Kasada, C.; Shinpo, A.; Suga, S. J. Phys. Chem. B 2005, 109, 15476. (d) Tan, S.; Zhai, J.; Fang, H.; Jiu, T.; Ge, J.; Li, Y.; Jiang, L.; Zhu, D. Chem. -Eur. J. 2005, 11, 6272. (e) Hagberg, D. P.; Edvinsson, T.; Marinado, T.; Boschloo, G.; Hagfeldt, A.; Sun, L. Chem. Commun. 2006, 2245. (f) Li, S.-L.; Jiang, K.-J.; Shao, K.-F.; Yang, L.-M. Chem. Commun. 2006, 2792. (g) Koumura, N.; Wang, Z.-S.; Mori, S.; Miyashita, M.; Suzuki, E.; Hara, K. J. Am. Chem. Soc. 2006, 128 , 14256. (h) Kim, S.; Lee, J. K.; Kang, S. O.; Ko, J.; Yum, J.-H.; Fantacci, S.; De Angelis, F.; Censo, D. D.; Nazeeruddin, M. K.; Grätzel, M. J. Am. Chem. Soc. 2006, 128, 16701. (i) Chen, C.-Y.; Wu, S.-J.; Wu, C.-G.; Chen, J.-G.; Ho, K.-C. Angew. Chem., Int. Ed. 2006, 45, 1. (j) Choi, H.; Lee, J. K.; Song, K. H.; Song, K.; Kang, S. O.; Ko, J. Tetrahedron 2007, 63, 1553. (k) Kim, D.; Lee, J. K.; Kang, S. O.; Ko, J. Tetrahedron 2007, 63, 1913. (1) Choi, H.; Lee, J. K.; Song, K.; Kang, S. O.; Ko, J. Tetrahedron 2007, 63, 3115. (m) Qin, P.; Yang, X.; Chen, R.; Sun, L.; Marinado, T.; Edvinsson, T.; Boschloo, G.; Hagfeldt, A. J. Phys. Chem. C 2007, 111, 1853. (n) Chen, R.; Yang, X.; Tian, H.; Sun, L. J. Photochem. Photobiol., A 2007, 189, 295. (o) Kim, S.; Choi, H.; Kim, D.; Song, K.; Kang, S. O.; Ko, J. Tetrahedron 2007, 63, 9206.

(13) Robertson, N. Angew. Chem., Int. Ed. 2006, 45, 2338.

(14) (a) Granström, M.; Petritsch, K.; Arias, A. C.; Lux, A.; Andersson, M. R.; Friend, R. H. Nature 1998, 395, 257. (b) Camaioni, N.; Garlaschelli, L.; Geri, A.; Maggini, M.; Possamai, G.; Ridolfi, G. J. Mater. Chem. 2002, 12, 2065. (c) Cremer, J.; Mena-Osterritz, E.; Pschierer, N. G.; Müllen, K.; Bäuerle, P. Org. Biomol. Chem. 2005, 3, 985. (d) Cremer, J.; Bäuerle, P. J. Mater. Chem. 2006, 16, 874. (e) Cravino, A.; Roquet, S.; Alévêque, O.; Leriche, P.; Frère, P.; Roncali, J. Chem. Mater. 2006, 18, 2584. (f) Sivula, K.; Luscombe, C. K.; Thompson, B. C.; Fréchet, J. M. J. J. Am. Chem. Soc. 2006, 128, 13988. (g) Hiorns, R. C.; de Bettignies, R.; Leroy, J.; Bailly, S.; Firon, M.; Sentein, C.; Khoukh, A.; Preud'homme, H.; Dagron-Lartigau, C. Adv. Funct. Mater. 2006, 16, 2263.

(15) (a) Chen, L. T.; Tam, W.; Stevenson, S. H.; Meredith, G. R.; Rikken, G.; Marder, S. R. J. Phys. Chem. 1991, 95, 10631. (b) Hansch, C.; Leo, A.; Taft, R. W. Chem. Rev. 1991, 91, 165.
Herein, we report the design and synthesis of a new series of arylamine/cyanoacrylic acid dyes containing 2,3-disubstituted thiophene and/or oligothiophene as the spacers. With these dyes as the sensitizers, DSSCs of good performance were also fabricated. Studies of the transient photovoltage and electrochemical impedance are in support of retarded charge transfer of $\mathrm{TiO}_{2}\left(\mathrm{e}^{-}\right)$with both oxidized sensitizer and $\mathrm{I}_{3}^{-}$.

\section{Experimental Section}

General Information. All reactions and manipulations were carried out under $\mathrm{N}_{2}$ with the use of standard inert atmosphere and Schlenk techniques. Solvents were dried by standard procedures. All column chromatography was performed under $\mathrm{N}_{2}$ with the use of silica gel (230-400 mesh, Macherey-Nagel GmbH \& Co.) as the stationary phase in a column $30 \mathrm{~cm}$ long and $2.0 \mathrm{~cm}$ in diameter. The ${ }^{1} \mathrm{H}$ and ${ }^{13} \mathrm{C}$ NMR spectra were measured with a Bruker AMX400 or AV400 spectrometer. Mass spectra were recorded on a JMS-700 double focusing mass spectrometer (JEOL, Tokyo, Japan). Elemental analyses were performed on a Perkin-Elmer 2400 $\mathrm{CHN}$ analyzer. Cyclic voltammetry experiments were performed with a $\mathrm{CH}$ Instruments electrochemical analyzer. All measurements were carried out at room temperature with a conventional threeelectrode configuration consisting of a platinum working electrode, a platinum wire auxiliary electrode, and a nonaqueous $\mathrm{Ag} / \mathrm{AgNO}_{3}$ reference electrode. The $E_{1 / 2}$ values were determined as $\left(E_{\mathrm{pa}}+E_{\mathrm{pc}}\right) /$ 2, where $E_{\mathrm{pa}}$ and $E_{\mathrm{pc}}$ are the anodic and cathodic peak potentials, respectively. The potentials are quoted against the ferrocene internal standard. The solvent in all experiments was tetrahydrofuran, and the supporting electrolyte was $0.1 \mathrm{M}$ tetrabutylammonium hexafluorophosphate. Electronic absorption spectra were obtained on a Cary 50 Probe UV-visible spectrophotometer.

4-(3'-( $N, N$-Diphenyl-4-(5-thiophen-2-yl)benzenamine)-2,2'bithiophen-5-yl)- $N, N$-diphenylbenzen-amine (1a). $N, N$-Diphenyl4-(5-(tributylstannyl)thiophen-2-yl)aniline (7.4 g, $12 \mathrm{mmol})$ generated from $N, N$-diphenyl-4-(thiophen-2-yl)aniline $(3.92 \mathrm{~g}, 12$ $\mathrm{mmol}), n$-butyl lithium $(8.2 \mathrm{~mL}, 1.6 \mathrm{M}, 13 \mathrm{mmol})$, and tri $(n-$ butyl)tin chloride $(4.23 \mathrm{~g}, 13 \mathrm{mmol})$ was treated with 2,3dibromothiophene $(2.42 \mathrm{~g}, 10 \mathrm{mmol})$ in the presence of $\mathrm{Pd}\left(\mathrm{PPh}_{3}\right)_{2} \mathrm{Cl}_{2}(0.070 \mathrm{~g}, 0.1 \mathrm{mmol})$ in dimethyl formamide $(10 \mathrm{~mL})$ for $17 \mathrm{~h}$ at $70^{\circ} \mathrm{C}$. After the completion of the reaction, the mixture was cooled and poured into cooled methanol $(100 \mathrm{~mL})$. A colorless precipitate formed. It was then filtered and purified by column chromatography on silica gel using hexane/dichloromethane mixture (4:1) as eluent. Yield: $5.00 \mathrm{~g}(68 \%)$. Colorless solid. ${ }^{1} \mathrm{H}$ NMR $\left(\mathrm{CDCl}_{3}\right): \delta$ 7.01-7.05 (m, $\left.8 \mathrm{H}\right), 7.10-7.13(\mathrm{~m}, 10 \mathrm{H}), 7.18(\mathrm{~d}, J=$ $5.3 \mathrm{~Hz}, 1 \mathrm{H}), 7.23-7.27(\mathrm{~m}, 10 \mathrm{H}), 7.42-7.44(\mathrm{~m}, 5 \mathrm{H}) .{ }^{13} \mathrm{C}$ NMR $\left(\mathrm{CDCl}_{3}\right): \delta 147.4,147.3,147.2,145.4,144.0,136.0,133.3,132.0$, $131.4,129.8,129.3,129.2,128.9,128.3,128.0,127.5,126.5,124.5$, 124.4, 123.6, 123.5, 123.1, 123.0, 122.3. FAB Mass $m / z: 734.2$ $\left[\mathrm{M}^{+}\right]$.

4,5-Bis(5-(4-(diphenylamino)phenyl)thiophen-2-yl)thiophene2-carbaldehyde (1b). A tetrahydrofuran $(50 \mathrm{~mL})$ solution of $\mathbf{1 a}$ $(3.68 \mathrm{~g}, 5 \mathrm{mmol})$ was cooled to $-20{ }^{\circ} \mathrm{C} . n$-Butyl lithium $(3.5 \mathrm{~mL}$, $1.6 \mathrm{M}, 6 \mathrm{mmol}$ ) was added dropwise over $15 \mathrm{~min}$ to the above mixture while the temperature was kept below $-10^{\circ} \mathrm{C}$. After stirring for an additional $2 \mathrm{~h}$, dry DMF $(2 \mathrm{~mL})$ was added at once. It was allowed to attain room temperature slowly and stirred overnight. The reaction was quenched by the addition of cooled aqueous ammonium chloride solution. The organic product was extracted with diethyl ether. The collected diethyl ether extracts were dried over $\mathrm{MgSO}_{4}$ and filtered, and evaporation of the filtrate produced the crude product, which was further purified by column 
Scheme 1. Outline of the Synthetic Scheme for 1-3
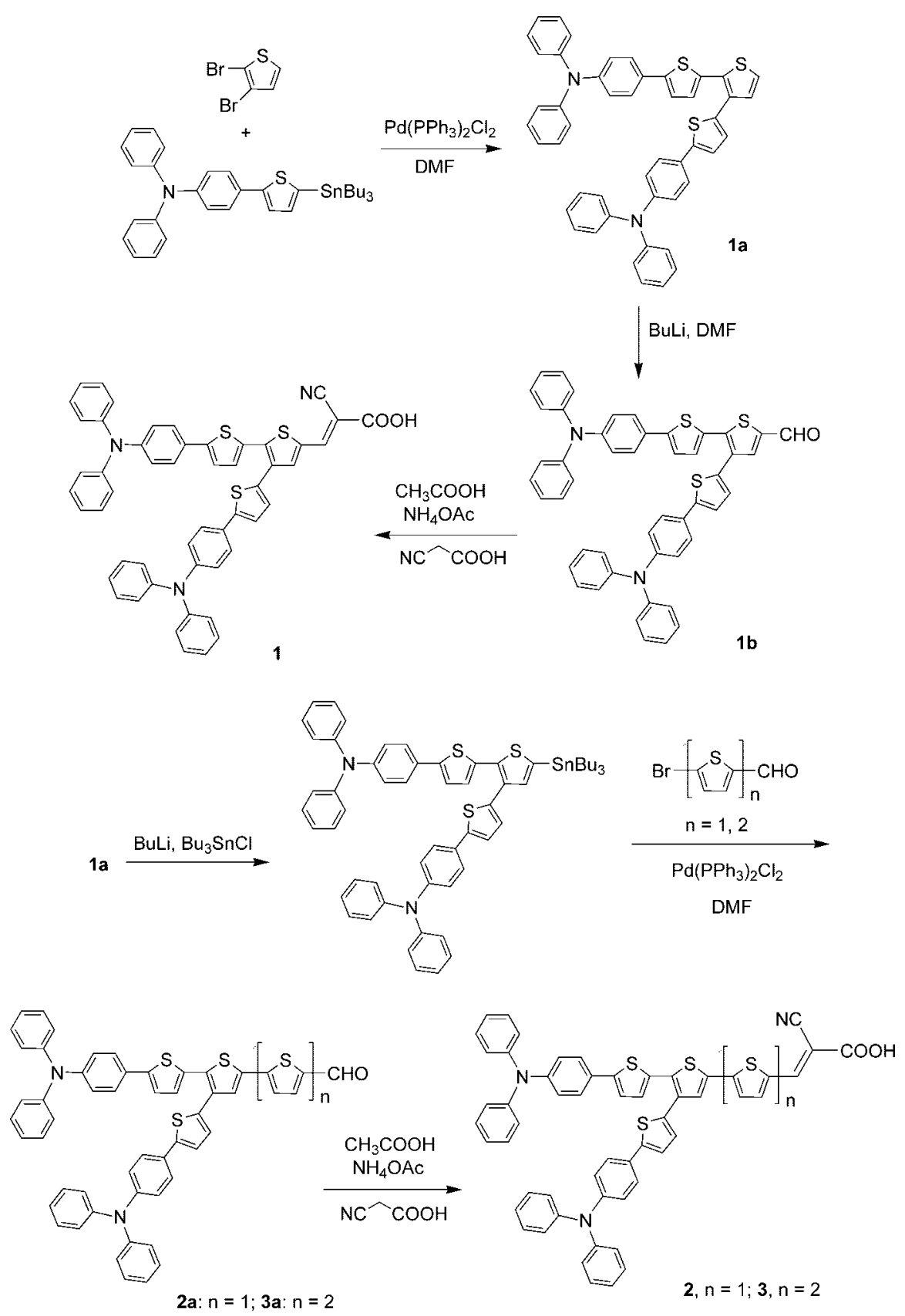

chromatography on silica gel using a hexane/dichloromethane mixture (1:1) as eluent. Yield: $1.53 \mathrm{~g}(40 \%)$. Yellow solid. ${ }^{1} \mathrm{H}$ NMR $\left(\mathrm{CDCl}_{3}\right): \delta 7.02-7.04(\mathrm{~m}, 8 \mathrm{H}), 7.08-7.11(\mathrm{~m}, 9 \mathrm{H}), 7.18(\mathrm{~d}, J=$ $5.2 \mathrm{~Hz}, 1 \mathrm{H}), 7.22-7.27$ (m, $9 \mathrm{H}), 7.37-7.43$ (m, 4 H), 7.73 (s, 1 $\mathrm{H}), 9.85(\mathrm{~s}, 1 \mathrm{H}) .{ }^{13} \mathrm{C} \mathrm{NMR}\left(\mathrm{CDCl}_{3}\right): \delta 182.4,147.9,147.5,147.3$, $147.25,147.2,145.4,142.4,140.1,139.1,133.8,132.1,131.9$, $129.8,129.3,129.2,128.8,127.7,127.1,126.6,126.5,124.7,124.6$, $123.4,123.3,123.2,123.1,122.5,122.4$. FAB Mass $m / z: 763.2$ $[\mathrm{M}+\mathrm{H}]^{+}$.

(E)-3-(4,5-Bis(5-(4-(diphenylamino)phenyl)thiophen-2-yl)thiophen-2-yl)-2-cyanoacrylic acid (1). The compound $\mathbf{1 b}(0.763$ $\mathrm{g}, 1 \mathrm{mmol})$, cyanoacetic acid $(0.255 \mathrm{~g}, 3 \mathrm{mmol})$, ammonium acetate $(30 \mathrm{mg})$ and glacial acetic acid $(10 \mathrm{~mL})$ were mixed together and heated at boiling temperature for $12 \mathrm{~h}$. The clear red solution formed was cooled to room temperature to yield a dark colored precipitate. It was filtered and thoroughly washed with cooled acetic acid $(2 \times$ $20 \mathrm{~mL})$, water $(3 \times 30 \mathrm{~mL})$, and a hexane/diethylether $(1: 1, \mathrm{v} / \mathrm{v})$ mixture $(3 \times 20 \mathrm{~mL})$. A red precipitate was then obtained and further purified by crystallization from the dichloromethane/hexane mixture. Yield: $0.68 \mathrm{~g}(82 \%)$. Red solid. ${ }^{1} \mathrm{H}$ NMR $\left(\mathrm{CDCl}_{3}\right): \delta$ 6.88-6.94 (m, 4 H), 7.00-7.07 (m, $12 \mathrm{H}), 7.21(\mathrm{~d}, J=4.0 \mathrm{~Hz}, 1$ H), 7.27-7.38 (m, $11 \mathrm{H}), 7.47-7.51(\mathrm{~m}, 4 \mathrm{H}), 8.08$ (s, $1 \mathrm{H}), 8.46$ $(\mathrm{s}, 1 \mathrm{H}) .{ }^{13} \mathrm{C}$ NMR $\left(\mathrm{CDCl}_{3}\right): \delta 163.5,147.7,147.3,147.0,146.9$, $145.9,144.9,142.1,140.0,133.5,133.1,131.8,131.1,130.9,129.9$, 129.8, 127.3, 126.9, 126.7, 126.6, 124.8, 124.6, 123.9, 123.7, 123.4, 123.2, 122.7, 116.6, 100.4. FAB Mass $m / z: 829.1[\mathrm{M}]^{+}$. HRMS: 829.1878 (calcd for $\mathrm{C}_{52} \mathrm{H}_{35} \mathrm{O}_{2} \mathrm{~N}_{3} \mathrm{~S}_{3}: 829.1891$ ).

5-(4,5-Bis(5-(4-(diphenylamino)phenyl)thiophen-2-yl)thiophen2-yl)thiophene-2-carbaldehyde (2a). A tetrahydrofuran $(50 \mathrm{~mL})$ solution of $1 \mathrm{a}(3.68 \mathrm{~g}, 5 \mathrm{mmol})$ was cooled to $-20{ }^{\circ} \mathrm{C}$. $n$-Butyl lithium $(3.5 \mathrm{~mL}, 1.6 \mathrm{M}, 6 \mathrm{mmol}$ ) was added dropwise over $15 \mathrm{~min}$ to the above mixture with the temperature maintained below -10 ${ }^{\circ} \mathrm{C}$. After the solution was stirred for an additional $2 \mathrm{~h}, \mathrm{Bu}_{3} \mathrm{SnCl}$ $(1.95 \mathrm{~g}, 6 \mathrm{mmol})$ was added and the solution stirred at room temperature overnight. The reaction was quenched by the addition of cooled water and the organic product extracted with diethyl ether. 
The dried (over $\mathrm{MgSO}_{4}$ ) diethyl ether extracts were concentrated to obtain the stannylene derivative of $\mathbf{1 a}$. The crude tin reagent was treated with 5-bromothiophene-2-carbaldehyde (0.86, 4.5 mmol) using $\mathrm{Pd}\left(\mathrm{PPh}_{3}\right)_{2} \mathrm{Cl}_{2}(35 \mathrm{mg})$ as catalyst in dimethyl formamide $(10 \mathrm{~mL})$. The reaction was maintained at $70{ }^{\circ} \mathrm{C}$ for $17 \mathrm{~h}$. Subsequently, it was cooled and poured into ice-cooled methanol to obtain yellow precipitate, followed by the purification by column chromatography on silica gel using a hexane/dichloromethane mixture (1:1) as eluent. Yield: $2.85 \mathrm{~g}(75 \%)$. Yellow solid. NMR $\left(\mathrm{CDCl}_{3}\right): \delta 7.0-7.13(\mathrm{~m}, 20 \mathrm{H}), 7.22-7.27(\mathrm{~m}, 9 \mathrm{H}), 7.37-7.44(\mathrm{~m}$, $5 \mathrm{H}), 7.66(\mathrm{~d}, J=4.0 \mathrm{~Hz}, 1 \mathrm{H}), 9.85(\mathrm{~s}, 1 \mathrm{H}) .{ }^{13} \mathrm{C} \mathrm{NMR}\left(\mathrm{CDCl}_{3}\right)$ : $\delta 182.4,147.7,147.4,147.3,146.2,146.1,142.0,137.2,134.6$, 133.8, 133.6, 132.6, 132.4, 129.3, 129.1, 128.7, 128.3, 128.0, 127.6, $126.6,126.5,124.6,124.55,124.4,123.5,123.3,123.26,123.2$, $122.5,122.4$, FAB Mass $m / z: 789.1[\mathrm{M}+\mathrm{H}]^{+}$. HRMS: 844.1705 (calcd for $\mathrm{C}_{53} \mathrm{H}_{36} \mathrm{~N}_{2} \mathrm{OS}_{4}$ : 844.171).

(E)-3-(5-(4,5-Bis(5-(4-(diphenylamino)phenyl)thiophen-2-yl)thiophen-2-yl)thiophen-2-yl)-2-cyanoacrylic acid (2). 2 was prepared from $\mathbf{2 a}$ with a method similar to that described earlier for 1. Yield: $79 \%$. Red solid. ${ }^{1} \mathrm{H}$ NMR $\left(\mathrm{CDCl}_{3}\right): \delta 6.88-7.01(\mathrm{~m}, 16$ H), 7.18-7.31 (m, 12 H), 7.41-7.49 (m, $4 \mathrm{H}), 7.60$ (s, $1 \mathrm{H}), 7.72$ $(\mathrm{s}, 1 \mathrm{H}), 7.95(\mathrm{~s}, 1 \mathrm{H}), 8.45(\mathrm{~s}, 1 \mathrm{H}) .{ }^{13} \mathrm{C} \mathrm{NMR}\left(\mathrm{CDCl}_{3}\right): \delta 163.7$, 147.5, 147.2, 147.0, 146.9, 146.4, 145.6, 144.5, 144.3, 141.4, 134.8, $134.0,133.7,132.8,132.4,131.5,130.2,129.8,129.5,129.2,127.5$, 127.0, 126.7, 126.6, 125.9, 124.6, 124.5, 123.8, 123.6, 123.2, 123.0, 116.7, 98.8. FAB Mass $m / z: 912.19[\mathrm{M}+\mathrm{H}]^{+}$. HRMS: 911.1765 (calcd for $\mathrm{C}_{56} \mathrm{H}_{37} \mathrm{O}_{2} \mathrm{~N}_{3} \mathrm{~S}_{4}$ : 911.1769).

5-(5-(4,5-Bis(5-(4-(diphenylamino)phenyl)thiophen-2-yl)thiophen-2-yl)thiophen-2-yl)thiophene-2-carbaldehyde (3a). 3a was obtained in $81 \%$ yield following the procedure described for $\mathbf{2 a}$ except that 5'-bromo-2,2'-bithiophene-5-carbaldehyde was used to replace 5-bromothiophene-2-carbaldehyde. Orange solid. ${ }^{1} \mathrm{H}$ NMR $\left(\mathrm{CDCl}_{3}\right): \delta 7.02-7.04(\mathrm{~m}, 10 \mathrm{H}), 7.08-7.11(\mathrm{~m}, 13 \mathrm{H}), 7.22-7.27$ $(\mathrm{m}, 13 \mathrm{H}), 7.38-7.44(\mathrm{~m}, 5 \mathrm{H}), 7.63(\mathrm{~d}, J=4.0 \mathrm{~Hz}, 1 \mathrm{H}), 9.83$ (s, $1 \mathrm{H}) .{ }^{13} \mathrm{C} \mathrm{NMR}\left(\mathrm{CDCl}_{3}\right): \delta 182.3,147.6,147.4,147.35,146.6$, 145.7, 144.6, 141.7, 138.2, 137.2, 135.1, 134.9, 134.4, 132.7, 132.3, $131.6,129.3,128.8,128.1,127.7,127.0,126.5,124.9,124.6,124.5$, 124.2, 123.6, 123.4, 123.2, 123.1, 122.4, 122.3. FAB Mass $m / z$ : $927.3[\mathrm{M}+\mathrm{H}]^{+}$. HRMS: 927.1672 (calcd for $\mathrm{C}_{57} \mathrm{H}_{39} \mathrm{ON}_{2} \mathrm{~S}_{5}$ : 927.1666).

(E)-3-(5-(5-(4,5-Bis(5-(4-(diphenylamino)phenyl)thiophen-2yl)thiophen-2-yl)thiophen-2-yl)thiophen-2-yl)-2-cyanoacrylic acid (3). 3 was prepared from $\mathbf{3 a}$ as described earlier for 1. Yield: $73 \%$. Deep red solid. ${ }^{1} \mathrm{H} \mathrm{NMR}\left(\mathrm{CDCl}_{3}\right): \delta 6.87-6.91(\mathrm{~m}, 4 \mathrm{H}), 6.98-7.06$ $(\mathrm{m}, 12 \mathrm{H}), 7.19(\mathrm{~d}, J=4.0 \mathrm{~Hz}, 1 \mathrm{H}), 7.25-7.32(\mathrm{~m}, 11 \mathrm{H})$, 7.41-7.46 (m, 5 H), 7.54-7.58 (m, $3 \mathrm{H}), 7.92(\mathrm{~d}, J=4.0 \mathrm{~Hz}, 1 \mathrm{H})$, $8.43(\mathrm{~s}, 1 \mathrm{H}) .{ }^{13} \mathrm{C} \mathrm{NMR}\left(\mathrm{CDCl}_{3}\right): \delta 163.7,147.3,147.0,146.9$, 146.3, 145.3, 145.2, 144.0, 141.4, 137.3, 134.5, 134.4, 132.6, 131.8, $130.2,130.0,129.8,129.1,128.2,127.6,127.1,126.6,126.55$, 126.4, 125.4, 124.6, 124.5, 123.7, 123.6, 123.3, 123.2, 123.0, 116.7, 98.5. FAB Mass $m / z: 993.2[\mathrm{M}]^{+}$. HRMS: 994.1729 (calcd for $[\mathrm{M}+\mathrm{H}]^{+} \mathrm{C}_{60} \mathrm{H}_{40} \mathrm{O}_{2} \mathrm{~N}_{3} \mathrm{~S}_{5}$ : 994.1724).

5'-(4-(Diphenylamino)phenyl)-2,2'-bithiophene-5-carbaldehyde (4a). First, the tin reagent $N, N$-diphenyl-4-(5-(tributylstannyl)thiophen-2-yl)aniline $(7.4 \mathrm{~g}, 12 \mathrm{mmol})$ was prepared by the treatment of $\mathrm{N}, \mathrm{N}$-diphenyl-4-(thiophen-2-yl)aniline (3.92 g, 12 mmol) with $n$-butyl lithium $(8.2 \mathrm{~mL}, 1.6 \mathrm{M}, 13 \mathrm{mmol})$ at $-20{ }^{\circ} \mathrm{C}$ in tetrahydrofuran and followed by the quenching of the lithium salt formed with tri( $n$-butyl)tin chloride $(4.23 \mathrm{~g}, 13 \mathrm{mmol})$. The isolated stannylene derivative was treated with 5-bromothiophene2-carbaldehyde $(1.91 \mathrm{~g}, 10 \mathrm{mmol})$ in the presence of Pd$\left(\mathrm{PPh}_{3}\right)_{2} \mathrm{Cl}_{2}(0.070 \mathrm{~g}, 0.1 \mathrm{mmol})$ under the Stille reaction conditions $\left(10 \mathrm{~mL}\right.$ DMF, $70{ }^{\circ} \mathrm{C}, 17 \mathrm{~h}$ ). The mixture was then cooled and poured into large amount of cold methanol $(100 \mathrm{~mL})$. A light yellow precipitate formed and was separated by filtration and purified by column chromatography on silica gel using a hexane/dichloromethane mixture (1:1) as eluent. Yield: $74 \%$. Pale yellow solid. ${ }^{1} \mathrm{H}$ NMR $\left(\mathrm{CDCl}_{3}\right): \delta$ 7.03-7.07 (m, $\left.4 \mathrm{H}\right), 7.10-7.15$ (m, $\left.5 \mathrm{H}\right), 7.22$ $(\mathrm{d}, J=4.0 \mathrm{~Hz}, 1 \mathrm{H}), 7.25-7.30(\mathrm{~m}, 6 \mathrm{H}), 7.42-7.46(\mathrm{~m}, 2 \mathrm{H}), 7.64$ $(\mathrm{d}, J=4.0 \mathrm{~Hz}, 1 \mathrm{H}) .{ }^{13} \mathrm{C} \mathrm{NMR}\left(\mathrm{CDCl}_{3}\right): \delta 182.3,148.0,147.4$, 147.2, 146.3, 141.3, 137.4, 134.1, 129.4, 127.2, 127.1, 126.6, 124.8, 123.7, 123.5, 123.2, 123.1. FAB Mass $m / z: 437.2[\mathrm{M}+\mathrm{H}]^{+}$. HRMS: 437.0904 (calcd for $\mathrm{C}_{27} \mathrm{H}_{19} \mathrm{ONS}_{2}$ : 437.0908).

(E)-2-Cyano-3-(5-(5-(4-(diphenylamino)phenyl)thiophen-2yl)thiophen-2-yl)acrylic acid (4). 4 was prepared from 4a with a method similar to that described above for 1 . Yield: $74 \%$. Red solid. ${ }^{1} \mathrm{H} \mathrm{NMR}\left(\mathrm{CDCl}_{3}\right): \delta 6.92(\mathrm{~d}, J=8.6 \mathrm{~Hz}, 2 \mathrm{H}), 7.02-7.09(\mathrm{~m}, 6$ H), 7.28-7.33 (m, $4 \mathrm{H}), 7.43(\mathrm{~d}, J=4.0 \mathrm{~Hz}, 1 \mathrm{H}), 7.52(\mathrm{~d}, J=4.0$ $\mathrm{Hz}, 1 \mathrm{H}), 7.55-7.58$ (m, $3 \mathrm{H}), 7.93(\mathrm{~d}, J=4.0 \mathrm{~Hz}, 1 \mathrm{H}), 8.44$ (s, $1 \mathrm{H}) .{ }^{13} \mathrm{C} \mathrm{NMR}\left(\mathrm{CDCl}_{3}\right): \delta 163.9,147.8,146.9,146.6,146.1,145.7$, $141.7,133.9,133.3,129.9,128.6,126.9,126.6,124.9,124.5,124.0$, 122.6, 116.8, 97.9. FAB Mass $m / z: 504.2[\mathrm{M}]^{+}$. HRMS: 504.0977 (calcd for $\mathrm{C}_{30} \mathrm{H}_{20} \mathrm{O}_{2} \mathrm{~N}_{2} \mathrm{~S}_{2}$ : 504.0966).

5-(5-(5-(4-(Diphenylamino)phenyl)thiophen-2-yl)thiophen-2yl)thiophene-2-carbaldehyde (5a). 5a was prepared by following a procedure similar to that described above for $4 \mathbf{a}$ except that $5^{\prime}$ bromo-2,2'-bithiophene-5-carbaldehyde was used instead of 5-bromothiophene-2-carbaldehyde in the second step of the reaction. Yield: $81 \%$. Yellow solid. ${ }^{1} \mathrm{H}$ NMR $\left(\mathrm{CDCl}_{3}\right): \delta 7.01-7.15(\mathrm{~m}, 11$ H), 7.20-7.28 (m, 6 H), 7.43 (d, $J=8.6 \mathrm{~Hz}, 2 \mathrm{H}), 7.65$ (d, $J=4.0$ $\mathrm{Hz}, 1 \mathrm{H}), 9.84(\mathrm{~s}, 1 \mathrm{H}) .{ }^{13} \mathrm{C} \mathrm{NMR}\left(\mathrm{CDCl}_{3}\right): \delta 182.3,147.7,147.4$, 146.9, 144.3, 141.6, 139.4, 137.3, 134.6, 134.2, 129.4, 127.6, 127.0, $126.5,125.4,124.7,124.2,124.0,123.3,123.0$. FAB Mass $m / z$ : $519.1[\mathrm{M}+\mathrm{H}]^{+}$. HRMS: 519.0772 (calcd for $\mathrm{C}_{31} \mathrm{H}_{21} \mathrm{ONS}_{3}$ : 519.0785).

(E)-2-Cyano-3-(5-(5-(5-(4-(diphenylamino)phenyl)thiophen2-yl)thiophen-2-yl)thiophen-2-yl)acrylic acid (5). 5 was prepared from $\mathbf{5 a}$ as described above for $\mathbf{1}$. Yield: $86 \%$. Red solid. ${ }^{1} \mathrm{H}$ NMR $\left(\mathrm{CDCl}_{3}\right): \delta 6.95-6.98(\mathrm{~m}, 2 \mathrm{H}), 7.05-7.10(\mathrm{~m}, 6 \mathrm{H}), 7.31-7.35(\mathrm{~m}$, $4 \mathrm{H}), 7.39$ (d, $J=4.0 \mathrm{~Hz}, 1 \mathrm{H}), 7.41(\mathrm{~d}, J=4.0 \mathrm{~Hz}, 1 \mathrm{H}), 7.44(\mathrm{~d}$, $J=4.0 \mathrm{~Hz}, 1 \mathrm{H}), 7.57-7.60(\mathrm{~m}, 4 \mathrm{H}), 7.97(\mathrm{~d}, J=4.0 \mathrm{~Hz}, 1 \mathrm{H})$, $8.47(\mathrm{~s}, 1 \mathrm{H}) \cdot{ }^{13} \mathrm{C} \mathrm{NMR}\left(\mathrm{CDCl}_{3}\right): \delta 163.8,147.4,147.0,146.5$, 145.5, 143.6, 141.7, 138.7, 134.2, 134.0, 133.6, 129.9, 128.4, 127.1, $126.7,125.5,125.3,124.7,124.2,123.8,123.0,116.8,98.2$. FAB Mass $m / z: 586.1[\mathrm{M}]^{+}$. HRMS: 586.0840 (calcd for $\mathrm{C}_{34} \mathrm{H}_{22} \mathrm{O}_{2 \mathrm{~N} 2} \mathrm{~S}_{3}$ : 586.0843).

Assembly and Characterization of DSSCs. The $\mathrm{TiO}_{2}$ thin film serving as the photoanode in this work was prepared through the general sol-gel method. The precursor solution was made according to the following procedure: $430 \mathrm{~mL}$ of $0.1 \mathrm{M}$ nitric acid solution under vigorous stirring was slowly combined with $72 \mathrm{~mL}$ $\mathrm{Ti}\left(\mathrm{C}_{3} \mathrm{H}_{7} \mathrm{O}\right)_{4}$ to form a mixture. After the hydrolysis, the mixture was heated at $85^{\circ} \mathrm{C}$ in a water bath and stirred vigorously for $8 \mathrm{~h}$ in order to achieve the peptization. When the mixture was cooled to room temperature, the resultant colloid was filtered, and the filtrate was then heated in an autoclave at a temperature of $240{ }^{\circ} \mathrm{C}$ for $12 \mathrm{~h}$ to grow the $\mathrm{TiO}_{2}$ particles. When the colloid was cooled to room temperature, it was ultrasonically vibrated for $10 \mathrm{~min}$. The $\mathrm{TiO}_{2}$ colloid was concentrated to $13 \mathrm{wt} \%$, followed by the addition of $30 \mathrm{wt} \%$ (with respect to $\mathrm{TiO}_{2}$ weight) of poly(ethylene glycol) (PEG, MW $=20000 \mathrm{~g} / \mathrm{mol}$ ) to prevent the film from cracking while drying. The $\mathrm{TiO}_{2}$ paste was then deposited on a FTO glass substrate by the glass rod method with a dimension of $0.5 \times 0.5 \mathrm{~cm}^{2}$. The $\mathrm{TiO}_{2}$-coated FTO was heated to $500{ }^{\circ} \mathrm{C}$ at a heating rate of 20 ${ }^{\circ} \mathrm{C} / \mathrm{min}$. and maintained for $30 \mathrm{~min}$ before being cooled to room temperature. The thickness of $\mathrm{TiO}_{2}$ film was controlled by repeating the procedure described above. A platinized FTO with a layer of Pt $100 \mathrm{~nm}$-thick applied by sputtering was used as a counter electrode. The active area was controlled at a dimension of $0.5 \times$ 
$0.5 \mathrm{~cm}^{2}$ by adhered polyester tape $(3 \mathrm{M})$ with a thickness of 60 $\mu \mathrm{m}$ on the Pt electrode. After heating of the $\mathrm{TiO}_{2}$ thin film to 80 ${ }^{\circ} \mathrm{C}$, the film was taken out from the oven and dipped into the THF solution containing $3 \times 10^{-4} \mathrm{M}$ dye sensitizers for at least $12 \mathrm{~h}$. Use of THF solution for dipping was meant to ensure enough uptakes of the sensitizers due to the higher solubility of the sensitizers in THF. After being rinsed with $\mathrm{CH}_{3} \mathrm{CN}$, the photoanode was placed on top of the counter electrode and tightly clipped to it to form a cell. Electrolyte was then injected into the space and the cell sealed with Torr Seal cement (Varian, MA). The electrolyte was composed of $0.5 \mathrm{M}$ lithium iodide (LiI), $0.05 \mathrm{M}$ iodine $\left(\mathrm{I}_{2}\right)$, and $0.5 \mathrm{M}$ 4-tert-butylpyridine dissolved in acetonitrile. Note that there was no mask used to constrain the illumination area of the device in this study; therefore, the power conversion efficiency and the corresponding measurements might be overestimated. ${ }^{16}$ However, our results were compared with the commercial N3 dye, which acted as a reference for each measurement, and the conditions for each device were identical. Therefore, we believe that the difference of the performance among the devices made in this study was mainly attributed to the intrinsic properties of the sensitizers. The adsorbed density of each dye was calculated from the difference in concentration of each solution before and after $\mathrm{TiO}_{2}$ film immersion. The thickness and the area of $\mathrm{TiO}_{2}$ film were controlled at $14 \mu \mathrm{m}$ and $3 \mathrm{~cm}^{2}$, respectively.

The photoelectrochemical characterizations on the solar cells were carried out using a modified light source, $450 \mathrm{~W}$ Xe lamp (Oriel, 6266) equipped with a water-based IR filter and AM 1.5 filter (Oriel, 81075). Light intensity, attenuated by neutral density filter (Optosigma, 078-0360) at the measuring (cell) position, was estimated to be ca. $100 \mathrm{~mW} / \mathrm{cm}^{2}$ according to the reading from a radiant power meter (Oriel, 70260) connected to a thermopile probe (Oriel, 70263). Photoelectrochemical characteristics of the DSSCs, including photocurrent-voltage curves and electrochemical impedance spectra, were recorded through the potentiostat/galvanostat (PGSTAT 30, Autolab, Eco-Chemie, Netherland). Electrochemical impedance spectra were recorded for DSSC under dark at -0.65 $\mathrm{V}$ potential at room temperature. The frequencies explored ranged from $10 \mathrm{mHz}$ to $65 \mathrm{kHz}$. The ac amplitude was set at $10 \mathrm{mV}$.

Measurement of Recombination Time Constant by Transient Photovoltage. The photovoltage transients of assembled devices were recorded with a digital oscilloscope (LeCroy, model LT322). Pulsed laser excitation was applied by a frequencydoubled Q-switched Nd:YAG laser (Spectra-Physics laser, model Quanta-Ray GCR-3-10) with $2 \mathrm{~Hz}$ repetition rate at $532 \mathrm{~nm}$ and $7 \mathrm{~ns}$ pulse width at half-height. The beam size was slightly larger than $0.25 \mathrm{~cm}^{2}$ to cover the area of the device with incident energy of $1 \mathrm{~mJ} / \mathrm{cm}^{2}$. The recombination lifetime of photoinjected electrons with oxidized dyes was measured by transient photovoltages at open circuit with the presence of $\mathrm{LiClO}_{4}$ or $\mathrm{LiI}$ electrolyte $(0.5 \mathrm{M})$. The average electron lifetime can be estimated approximately by fitting a decay of the open circuit voltage transient with $\exp \left(-t / \tau_{\mathrm{R}}\right)$, where $t$ is time and $\tau_{\mathrm{R}}$ is an average time constant before recombination.

Theoretical Approach Methodology. All calculations were done by the Gaussian 03 program. ${ }^{17}$ The geometries of $\mathbf{2}$ and $\mathbf{5}$ were optimized by the semiempirical PM3 method. ${ }^{18}$ The vertical

(16) Ito, S.; Nazeeruddin, Md. K.; Liska, P.; Comte, P.; Charvet, R.; Péchy, P.; Jirousek, M.; Kay, A.; Zakeerudine, M.; Grätzel, M. Prog. Photovoltaics 2006, 14, 589.
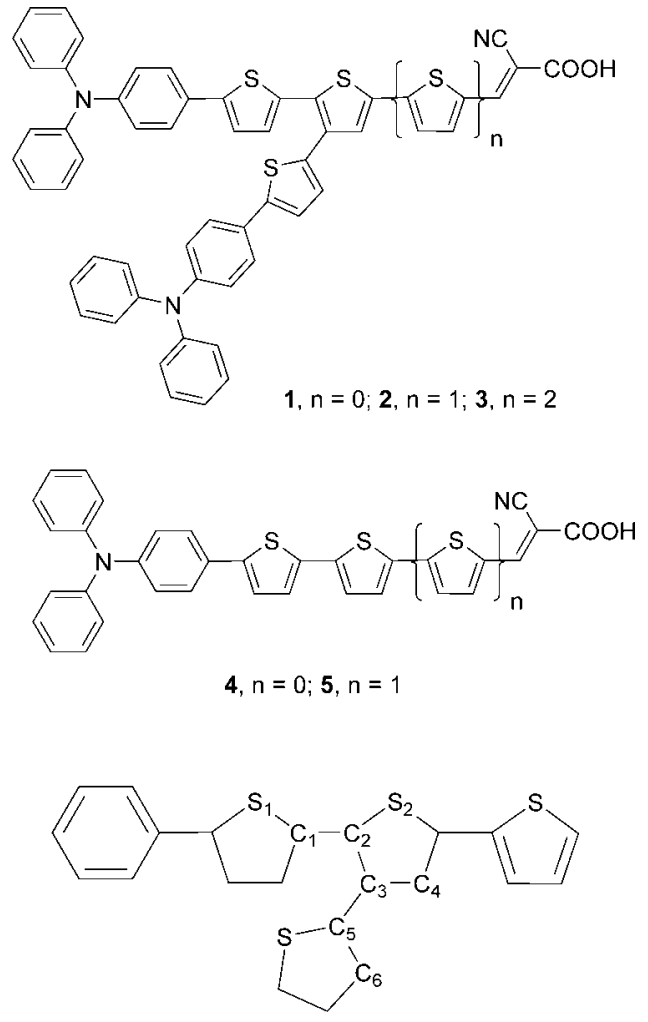

Figure 1. Structures of the compounds.

excitation energies of $\mathbf{2}$ and $\mathbf{5}$ were calculated using the ZINDO method on the basis of the optimized geometries. ${ }^{19}$

\section{Results and Discussion}

Synthesis of the Materials. The 2,3-disubstituted thiophenebased dyes $(\mathbf{1}-\mathbf{3})$ synthesized in this study are shown in Figure 1. 2-Substituted thiophene-based congeners (4-5) were also synthesized to allow a fair comparison. Synthetic sequences for $\mathbf{1 - 3}$ and $\mathbf{4 - 5}$ are illustrated in Schemes 1 and 2, respectively. Palladium-catalyzed Stille coupling reaction $^{20}$ of $\mathrm{N}, \mathrm{N}$-diphenyl-4-(5-(tributylstannyl)thiophen-2yl)aniline with 2,3-dibromothiophene provided 1a. Intermediate 1a was then converted to the corresponding thiophenealdehyde $\mathbf{1 b}$ by lithiation with $n$-butyl lithium and subsequently quenched with dimethylformamide. Finally, the aldehyde was allowed to react with cyanoacetic acid in

(17) Frisch, M. J.; Trucks, G. W.; Schlegel, H. B.; Scuseria, G. E.; Robb, M. A.; Cheeseman, J. R.; Montgomery, J. A.; Vreven, Jr., T.; Kudin, K. N.; Burant, J. C.; Millam, J. M.; Iyengar, S. S.; Tomasi, J.; Barone, V.; Mennucci, B.; Cossi, M.; Scalmani, G.; Rega, N.; Petersson, G. A.; Nakatsuji, H.; Hada, M.; Ehara, M.; Toyota, K.; Fukuda, R.; Hasegawa, J.; Ishida, M.; Nakajima, T.; Honda, Y.; Kitao, O.; Nakai, H.; Klene, M.; Li, X.; Knox, J. E.; Hratchian, H. P.; Cross, J. B.; Bakken, V.; Adamo, C.; Jaramillo, J.; Gomperts, R.; Stratmann, R. E.; Yazyev, O.; Austin, A. J.; Cammi, R.; Pomelli, C.; Ochterski, J. W.; Ayala, P. Y.; Morokuma, K.; Voth, G. A.; Salvador; P.; Dannenberg, J. J.; Zakrzewski, V. G.; Dapprich, S.; Daniels, A. D.; Strain, M. C.; Farkas, O.; Malick, D. K.; Rabuck, A. D.; Raghavachari, K.; Foresman, J. B.; Ortiz, J. V.; Cui, Q.; Baboul; A. G.; Clifford; S.; Cioslowski; J.; Stefanov, B. B.; Liu, G.; Liashenko, A.; Piskorz, P.; Komaromi, I. ; Martin, R. L.; Fox, D. J.; Keith, T.; Al-Laham, M. A.; Peng, C. Y.; Nanayakkara, A.; Challacombe, M.; Gill, P. M. W.; Johnson, B.; Chen, W.; Wong, M. W.; Gonzalez, C.; Pople, J. A.; Gaussian 03, Revision C.02; Gaussian, Inc.: Wallingford, CT, 2004.

(18) Stewart, J. J. P. J. Comput. Chem. 1989, 10, 209.

(19) Thompson, M. A.; Zerner, M. C. J. Am. Chem. Soc. 1991, 113, 8210.

(20) Stille, J. K. Angew. Chem., Int. Ed. 1986, 25, 508. 
Scheme 2. Outline of the Synthetic Scheme for 4-5

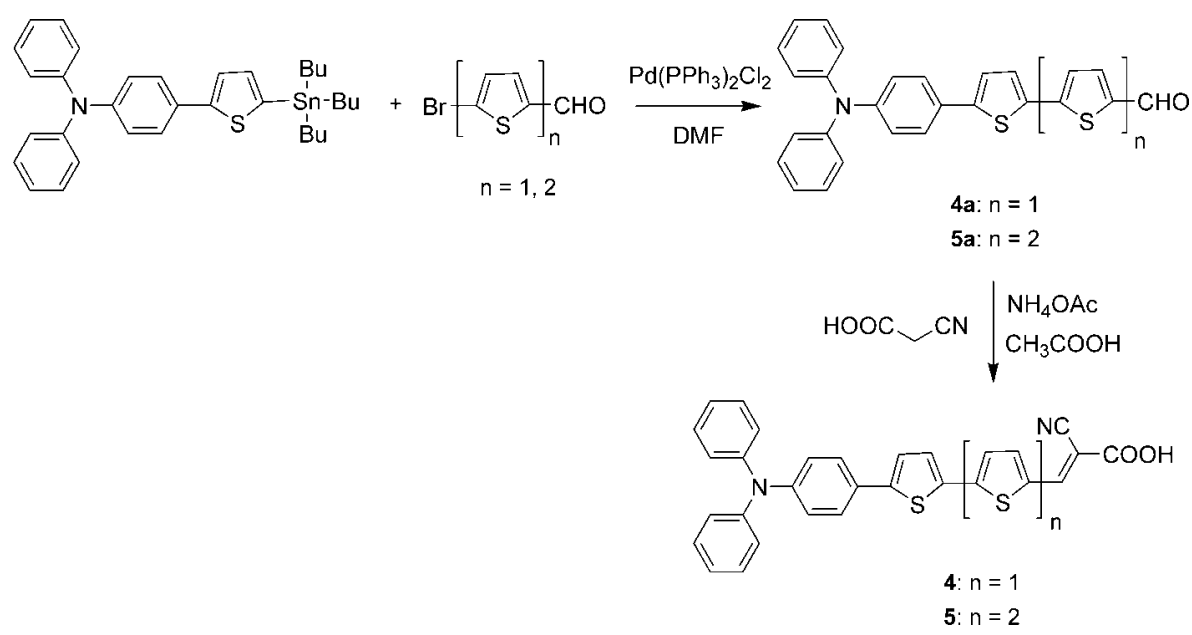

refluxing acetic acid in the presence of ammonium acetate to afford the desired dye $\mathbf{1}$. Compound $\mathbf{2}$ (or $\mathbf{3}$ ) was obtained from the Stille reaction of 5-bromothiophene-2-carbaldehyde (or 5'-bromo-2,2'-bithiophene-5-carbaldehyde) with the tributylstannyl derivatives of $\mathbf{1 a}$, followed by the reaction of aldehyde with cyanoacetic acid. Compounds $\mathbf{4}$ and $\mathbf{5}$ were prepared similarly, with the one difference being that $\mathrm{N}, \mathrm{N}$ diphenyl-4-(5-(tributylstannyl)thiophen-2-yl)aniline was utilized as the tin reagent.

Optical Properties. The absorption spectra of the dyes in THF solution are displayed in Figure 2a, and the corresponding data are presented in Table 1. All the dyes exhibit $\pi-\pi^{*}$ transition bands at $300-440 \mathrm{~nm}$, which are overlapped with a charge-transfer transition (from the triarylamine to the cyanoacrylic acid) at $\sim 460 \mathrm{~nm}$. The charge transfer band is blue-shifted as the solvent polarity increases (Figure 2b). This assignment is supported by the following observations: (a) 1a exhibits only $\pi-\pi^{*}$ transition bands $\left(\lambda_{\max }=302,366 \mathrm{~nm}\right)$, the peak wavelengths of which are nearly solvent polarity independent; (b) the charge transfer band of $\mathbf{1 b}$ (shown in Scheme 1) with the formyl group as the acceptor is further blue-shifted by $67 \mathrm{~nm}$ in THF as compared to that of $\mathbf{1}$. The more congested $\pi-\pi^{*}$ transition bands in $\mathbf{2}$ and $\mathbf{3}$ than in $\mathbf{1}$ may be attributed to the additional $\pi-\pi^{*}$ transitions upon extending the oligothiophene. As depicted in Figure 2a, compounds $\mathbf{1}-\mathbf{3}$ have a similar extinction coefficient in their $\pi-\pi^{*}$ transition band, while the extinction coefficient of the charge transfer transition band increases in the order of $\mathbf{1}<\mathbf{2}<\mathbf{3}$. A comparative examination of the absorption spectra between $\mathbf{4}$ and $\mathbf{1}$, and/ or 5 and $\mathbf{2}$, clearly indicates that the aforementioned $\pi-\pi^{*}$ transition bands also have contributions from the substituents at the $\mathrm{C}(3)$ position of the 2,3-substituted thiophene. The larger extinction coefficient of the $\pi-\pi^{*}$ transition band in $\mathbf{1}$ than in $\mathbf{4}$ (or in $\mathbf{2}$ than in $\mathbf{5}$ ) can be attributed to the presence of this C(3)-substituent in the former. In contrast, the charge transfer band has a larger extinction coefficient in $\mathbf{4}$ than in $\mathbf{1}$ (or in $\mathbf{5}$ than in 2). The results may tentatively be rationalized by the decrease of coplanarity between the electron donor (at the $\mathrm{C}(2)$ position) and the electron acceptor in the ground-state as well as in the Franck-Condon excited state because of the presence of the $\mathrm{C}(3)$-substituent. The charge transfer band exhibits negative solvatochromism, i.e., blue shift of $\lambda_{\max }$ in more polar solvents (Figure 2b), indicating that the titled compounds possess smaller dipole moments in the excited state than those in the ground state. One plausible rationalization lies in the fact that higher quantities of polar solvent decrease the electron-withdrawing power of the carboxylic acid due to its partial deprotonation in the excited state. Additional support of this viewpoint is rendered by the similar blue shift of $\lambda_{\max }$ upon $\mathrm{NEt}_{3}$ treatment of the THF solution of the dye: $435 \mathrm{~nm}$ for 1 and $449 \mathrm{~nm}$ for 4. Note that similar photophysical behavior has been reported for the black dye by Grätzel. ${ }^{1 \mathrm{~b}}$ As the $\mathrm{pH}$ of the solution is raised from 2 to 11 , the MLCT (metal-to-ligand charge-transfer) transition band shifts from 600 to $570 \mathrm{~nm}$ because of deprotonation of the carboxylic group. This type of negative solvatochromism is common for dipolar metalfree dyes based on our studies of several series of sensitizers, though it was scarcely mentioned in the literature. ${ }^{12 \mathrm{e}}$ Because of the low concentration used in this study $\left(<1 \times 10^{-5} \mathrm{M}\right)$, aggregation of the dyes ${ }^{21}$ is very unlikely, though a similar blue shift of the absorption is expected.

Blue shift of the absorption is also noted when the dyes are adsorbed on the $\mathrm{TiO}_{2}$ surface, and there is a larger shift in 4-5 than in 1-3 (Figure 3). Such blue shifts of the absorption spectra by adsorption on the $\mathrm{TiO}_{2}$ surface have also been observed in other metal-free organic dyes. ${ }^{11 \mathrm{a}, 12 \mathrm{c}, \mathrm{e}, \mathrm{f}}$ Either polar interaction with $\mathrm{TiO}_{2}$ and/or deprotonation of the carboxylic acid ${ }^{12 c, e}$ or $\mathrm{H}$-aggregation of the dyes ${ }^{12 \mathrm{f,o}}$ has been suggested to account for the spectral blue shift. In view of the fact that the dyes like $\mathbf{4}$ and $\mathbf{5}$ possess a flatter structure and hence have a greater tendency to undergo aggregation, we speculate that the formation of $\mathrm{H}$-aggregates on the $\mathrm{TiO}_{2}$ surface may greatly contribute to the blue shift of the absorption spectra. All the dyes reported in this study exhibit negligible emission both in the solution and on the $\mathrm{TiO}_{2}$ surface. Accordingly, the excited state is readily quenched, possibly by efficient intersystem crossing which is wellknown in oligothiophenes. ${ }^{22}$ Previously, we also noted that

(21) Cornil, J.; Beljionne, D.; Calbert, J.-P.; Brédas, J.-L. Adv. Mater. 2001, 13, 1053.

(22) (a) Kraabel, B.; Moses, D.; Heeger, A. J. J. Chem. Phys. 1995, 103, 5102. (b) Beljionne, D.; Cornil, J.; Friend, R. H.; Janssen, R. A.; Brédas, J. L. J. Am. Chem. Soc. 1996, 118, 6453.

(23) Su, Y. Z.; Lin, J. T.; Tao, Y.-T.; Ko, C.-W.; Lin, S.-C.; Sun, S.-S. Chem. Mater. 2002, 14, 1884. 

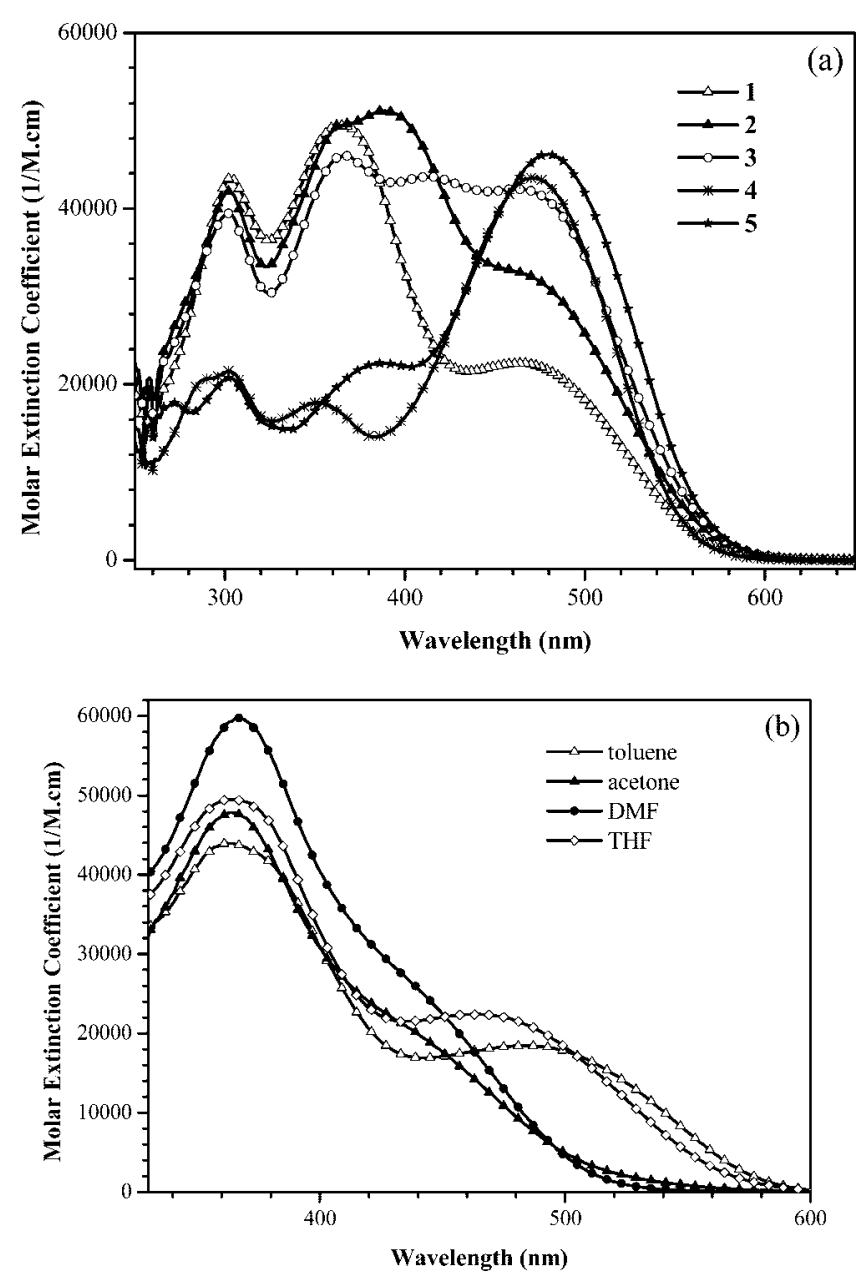

Figure 2. (a) Absorption spectra of compounds $\mathbf{1}-\mathbf{5}$ in THF solution. (b) Absorption spectra of $\mathbf{1}$ in different solvents.

oligothiophene-containing molecules tended to have low fluorescence quantum yields. ${ }^{23}$ For the case of the dyes adsorbed on the $\mathrm{TiO}_{2}$ surface, quenching of emission via the formation of $\mathrm{H}$-aggregates cannot be neglected, however.

Electrochemical Properties. The electrochemical data of the compounds are listed in Table 1. The dyes can be reversibly oxidized at moderately high oxidation potentials. Representative cyclic voltammograms are shown in Figure 4. For 1-3, a two-electron oxidation wave was detected. An one-electron oxidation wave at higher potential for $\mathbf{2}$ and 3 was attributed to the oligothiophene segment. Similarly, though only a one-electron oxidation of the amine was observed for $\mathbf{4}$ and $\mathbf{5}$, the latter exhibited an extra oxidation wave due to the presence of oligothiophene. It has been established unambiguously that the presence of three or more conjugated thiophenes is required for the observation of a reversible oxidation arising from the polythiophene segment. ${ }^{24}$ The excited-state potential $\left(E_{0-0}{ }^{*}\right)$ of the sensitizer was estimated from the first oxidation potential $\left(E_{\mathrm{ox}}\right)$ at the ground-state and the zero-zero excitation energy $\left(E_{0-0}\right)$ according to eq 1 , where the zero-zero excitation energy was estimated from the absorption onset. The thus deduced $E_{0-0} *$ values ( -0.92 to $-0.97 \mathrm{~V}$ vs NHE, see Table 1$)$ are more negative than the conduction-band-edge energy level of the $\mathrm{TiO}_{2}$ electrode, $-0.5 \mathrm{~V}$ vs NHE, ${ }^{25}$ indicating that the electron injection process is energetically favorable. On the other hand, the first oxidation potentials of the dyes $\left(1.20-1.26 \mathrm{~V}\right.$ vs NHE) are more positive than the $\mathrm{I}^{-} / \mathrm{I}_{3}{ }^{-}$ redox couple $\left(\sim 0.4 \mathrm{~V}\right.$ vs NHE). ${ }^{12 \mathrm{~g}, 26}$ The sufficiently low HOMO energy level of the dye will ensure more effective dye regeneration and suppress the recapture of the injected electrons by the dye cation radical.

$$
E_{0-0} *=E_{\mathrm{OX}}-E_{0-0}
$$

Photovoltaic Devices. DSSCs were fabricated using these dyes as the sensitizers, with an effective area of $0.25 \mathrm{~cm}^{2}$, nanocrystalline anatase $\mathrm{TiO}_{2}$ particles, and the electrolyte composed of $0.05 \mathrm{M} \mathrm{I}_{2} / 0.5 \mathrm{M} \mathrm{LiI} / 0.5 \mathrm{M}$ tert-butylpyridine in acetonitrile solution. The performance statistics of the DSSCs fabricated using these dyes as the sensitizers under AM 1.5 illumination are listed in Table 1. For comparison, one thienylfluorene dye $(\mathrm{FL})^{12 \mathrm{~b}}$ was also used for device fabrication. Figure 5 shows the photocurrent-voltage $(J-V)$ curves of the cells. The incident phototo-current conversion efficiencies (IPCE) of the dyes on $\mathrm{TiO}_{2}$ are presented in Figure 6. The performances of the devices manufactured with dyes $\mathbf{1}, \mathbf{2}$, and $\mathbf{4}$ are $>70 \%$ of the standard ruthenium dye N3. It is important to note that the adsorbed dye density is similar in different cells $\left(\mathbf{1}, 3.4 \times 10^{-7} ; \mathbf{2}, 3.6 \times 10^{-7} ; \mathbf{3}\right.$, $3.7 \times 10^{-7} ; \mathbf{4}, 3.7 \times 10^{-7} ; \mathbf{5}, 4.5 \times 10^{-7} \mathrm{~mol} / \mathrm{cm}^{2}$ ), and the influence of dye density on the cell performance can be considered unimportant in our later discussion. Incorporation of the 3-arylamine as a side chain does not seem to improve the efficiency of the DSSC for the shortest conjugation spacer in this study (i.e., 1 vs 4). However, the open-circuit voltage is improved upon incorporation of the 3-arylamine, i.e., $V_{\mathrm{OC}}$ (1) $>V_{\mathrm{OC}}(\mathbf{4})$ and $V_{\mathrm{OC}}(\mathbf{2})>V_{\mathrm{OC}}(\mathbf{5})$. We thus speculate that the extra hydrophobic side chain may retard the diffusion of the electrolyte to the surface of the $\mathrm{TiO}_{2}$, resulting in the suppression of the dark current and blocking of the cations, $\mathrm{Li}^{+}$and $\mathrm{H}^{+}$, from approaching the $\mathrm{TiO}_{2}$ surface. This result is reminiscent of the hydrophobic hydrocarbon chain used for Ru-based dyes ${ }^{27}$ and pure organic sensitizers. ${ }^{12 \mathrm{~g}, 28}$ The better light-harvesting of $\mathbf{4}$ than $\mathbf{1}$ should not be overlooked to account for the slightly better performance of 4- than 1-based cell. Though the relative position of hydrophobic alkyl chains may affect the $V_{\mathrm{OC}}$ values, ${ }^{27 \mathrm{a}}$ in comparison to $\mathbf{1}$ and $\mathbf{2}$, it is not certain whether the longer distance of the hydrophobic side chain in $\mathbf{3}$ to the $\mathrm{TiO}_{2}$ surface leads to the diminished $V_{\mathrm{OC}}$ (and efficiency as well). Deoxycholic acid was added to 3 as the coadsorbate $(1 \mathrm{mM})$ to suppress possible aggregation of $\mathbf{3}$ on the $\mathrm{TiO}_{2}$ surface. Though the performance of the thus fabricated device increased signifi-

(24) (a) Garcia, P.; Pernaut, J. M.; Hapiot, P.; Wintgens, V.; Valat, P.; Garnier, F.; Delabouglise, D. J. Phys. Chem. 1993, 97, 513. (b) Thomas, K. R. J.; Lin, J. T.; Wen, Y.-S. Organometallics 2000, 19, 1008.

(25) Hara, K.; Sato, T.; Katoh, R.; Furube, A.; Ohga, Y.; Shinpo, A.; Suga, S.; Sayama, K.; Sugihara, H.; Arakawa, H. J. Phys. Chem. B 2003, 107, 597.

(26) Hagfeldt, A.; Grätzel, M. Chem. Rev. 1995, 95, 49.

(27) (a) Zakeeruddin, S. M.; Nazeeruddin, M. K.; Humphry-Baker, R.; Péchy, P.; Quagliotto, P.; Barolo, C.; Viscardi, G.; Grätzel, M. Langmuir 2002, 18, 952. (b) Schmidt-Mende, L.; Kroeze, J. E.; Durrant, J. R.; Nazeeruddin, M. K.; Grätzel, M. Nano Lett. 2005, 5, 1315.

(28) Kroeze, J. E.; Hirata, N.; Koops, S.; Nazeeruddin, M. K.; SchmidtMende, L.; Grätzel, M.; Durrant, J. R. J. Am. Chem. Soc. 2006, 128, 16376. 
Table 1. Optical, Redox, and DSSCs Performance Parameters of the Dyes

\begin{tabular}{|c|c|c|c|c|c|c|c|c|}
\hline dye & $\lambda_{\mathrm{abs}}(\epsilon, 1 /(\mathrm{M} \mathrm{cm}))^{a}(\mathrm{~nm})$ & $E_{\mathrm{ox}}\left(\Delta E_{\mathrm{p}}\right)^{b}(\mathrm{~V})$ & $E_{0-0}^{c}(\mathrm{eV})$ & $E_{0-0} * d(\mathrm{~V})$ & $V_{\mathrm{OC}}{ }^{e}(\mathrm{~V})$ & $J_{\mathrm{SC}}^{e}\left(\mathrm{~mA} / \mathrm{cm}^{2}\right)$ & $f f^{e}$ & $\eta^{e}(\%)$ \\
\hline 1 & 462 (22400); 366 (49500); 303 (43400) & $0.49(92)$ & 2.18 & -0.92 & 0.68 & 14.5 & 0.61 & 5.95 \\
\hline 2 & $\begin{array}{l}465 \text { (32650); } 387(51100) ; 369 \text { (49750); } \\
\quad 302 \text { (41900) }\end{array}$ & 0.46 (100); $0.67(91)$ & 2.16 & -0.94 & 0.65 & 15.6 & 0.60 & 6.04 \\
\hline 4 & 473 (43500); 351 (17900); 302 (21450) & $0.49(108)$ & 2.20 & -0.96 & 0.63 & 16.0 & 0.61 & 6.15 \\
\hline 5 & 480 (46150); 386 (22350); 302 (20700) & $0.43(84), 0.57(65)$ & 2.17 & -0.97 & 0.61 & 15.2 & 0.58 & 5.41 \\
\hline FL & & & & & 0.69 & 17.0 & 0.62 & 7.19 \\
\hline
\end{tabular}

${ }^{a}$ The absorption spectra were recorded in THF. ${ }^{b}$ The cyclic voltammetric studies were conducted in THF. Scan rate, $100 \mathrm{mV} / \mathrm{s}$; electrolyte, $\left(n-\mathrm{C}_{4} \mathrm{H}_{9}\right)_{4} \mathrm{NPF}_{6} ; \Delta E_{\mathrm{p}}$ is the separation between the anodic and cathodic peaks and in unit of $\mathrm{mV}$. Potentials are quoted with reference to the internal ferrocene standard $\left(E_{1 / 2}=+265 \mathrm{mV}\right.$ vs $\left.\mathrm{Ag} / \mathrm{AgNO}_{3}\right)$. ${ }^{c}$ The bandgap, $E_{0-0}$, was derived from the observed optical edge. ${ }^{d} E_{0-0}{ }^{*}:$ The excited-state oxidation potential vs NHE. ${ }^{e}$ Experiments were conducted using $\mathrm{TiO}_{2}$ photoelectrodes with approximately $14 \mu \mathrm{m}$ thickness and $0.25 \mathrm{~cm}^{2}$ working area on the FTO (15 $\Omega /$ sq.) substrates. ${ }^{f}$ The cell was fabricated using the dye and with deoxycholic acid as a coadsorbate.

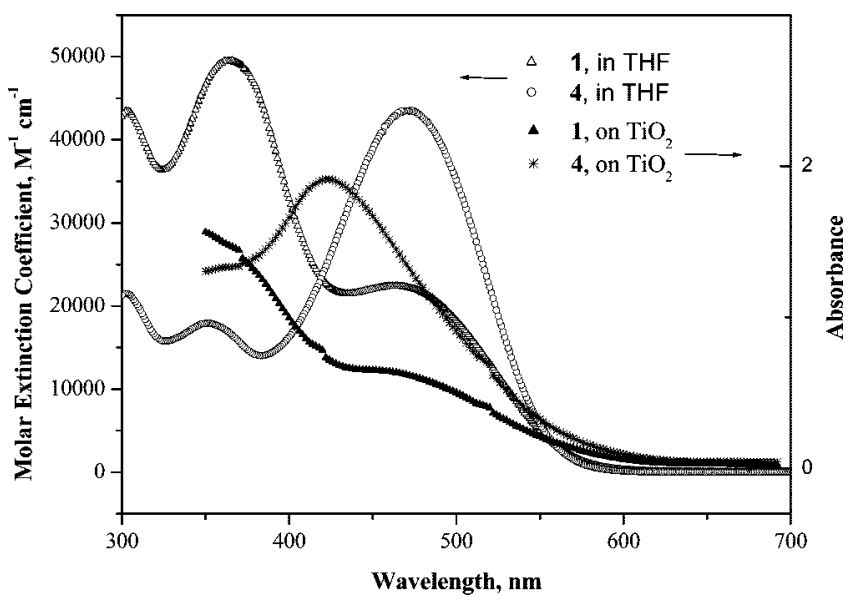

Figure 3. Absorption spectra of $\mathbf{1}$ and $\mathbf{4}$ in THF solution and on the $\mathrm{TiO}_{2}$ surface.

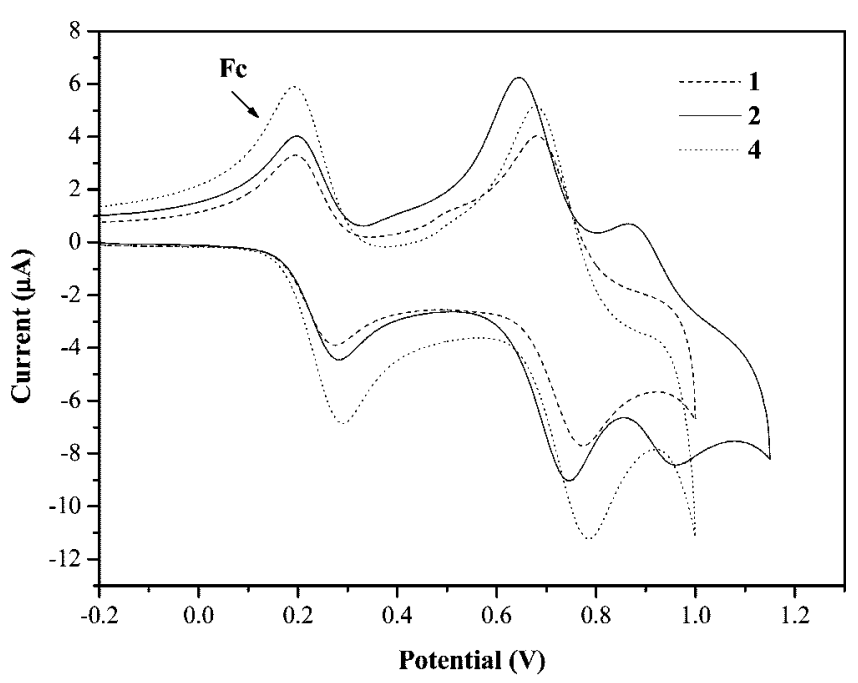

Figure 4. Cyclic voltammograms of compounds $\mathbf{1}, \mathbf{2}$, and $\mathbf{4}$ in THF. The ferrocene $(\mathrm{Fc})$ is the internal standard.

cantly (e.g., from 4.11 to $4.73 \%$ ), it was still inferior to other devices. Therefore, dye aggregation alone can not account for the relatively lower efficiency of the device $\mathbf{3}$ than others. It is believed that the comparatively higher-lying HOMO of 3 (estimated from the CV) also plays an important role due to its smaller driving force for the reduction of the oxidized dye. This, in turn, will lead to a faster back electron transfer from $\mathrm{TiO}_{2}$ to the dye and result in a smaller $\mathrm{V}_{\mathrm{OC}}$. In contrast, the comparatively lower-lying HOMO of $\mathbf{1}, \mathbf{2}$, and $\mathbf{4}$ should

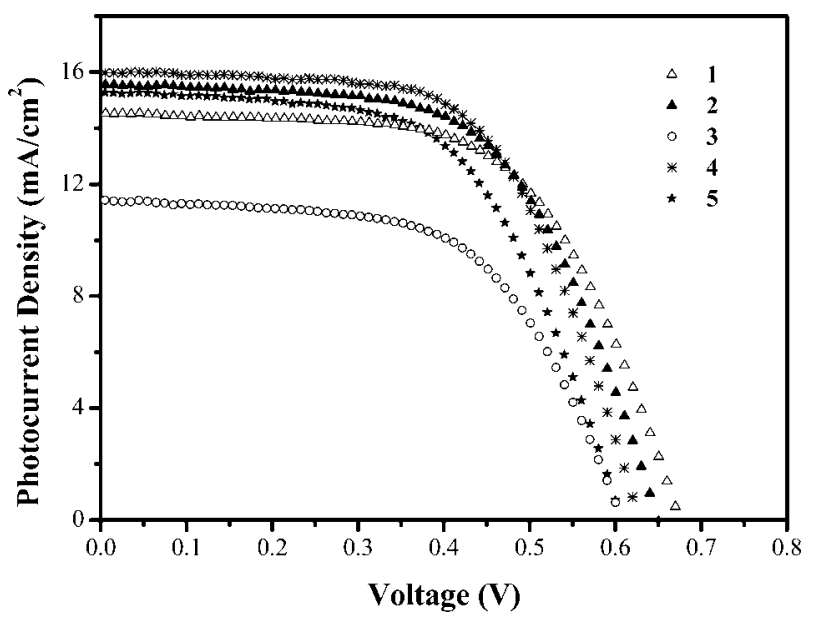

Figure 5. $J-V$ curves of DSSCs based on the dyes.

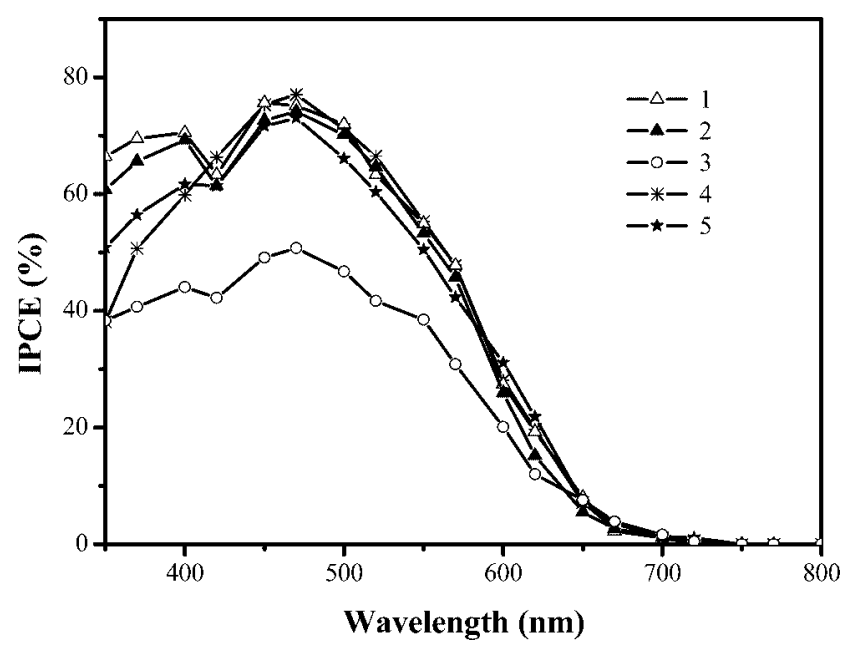

Figure 6. IPCE plots for the DSSCs using dyes 1-5.

lead to larger $V_{\mathrm{OC}}$ values. Cells using $\mathrm{TiO}_{2}$ of different thickness were also examined with the aim of optimizing the cell performance. The cell performance parameters are compiled in Table 2T. As the film thickness decreases, there is an increase in $V_{\mathrm{OC}}$ and a decrease in $J_{\mathrm{SC}}$ (short-circuit current). Among them, the cell with a $4 \mu \mathrm{m}$ film thickness exhibited the best conversion efficiency and filled factor. The thicker film apparently results in better light-harvesting at the expense of dark current suppression.

Although the absorbance near $600 \mathrm{~nm}$ of all the dyes is small when they are dissolved in the solvent, the IPCEs of 
Table 2. DSSC Performance Parameters of the Cells of 4 with Different $\mathrm{TiO}_{2}$ Film Thickness

\begin{tabular}{ccccc}
\hline cell $(\mu \mathrm{m})$ & $V_{\mathrm{OC}}(\mathrm{V})$ & $J_{\mathrm{SC}}\left(\mathrm{mA} / \mathrm{cm}^{2}\right)$ & $\eta(\%)$ & $\mathrm{FF}$ \\
\hline 4 & 0.68 & 14.17 & 6.40 & 0.66 \\
8 & 0.66 & 14.93 & 6.23 & 0.64 \\
11 & 0.65 & 15.44 & 6.26 & 0.62 \\
15 & 0.63 & 16.04 & 6.10 & 0.61
\end{tabular}

the solar cells in this region are measured to be above $20 \%$. The results indirectly support a strong interaction between the titled dyes and $\mathrm{TiO}_{2}$ and/or a significant aggregation effect of dyes on $\mathrm{TiO}_{2}$. From Figure 3, the extinction coefficients of $\mathbf{1}$ adsorbed on the $4 \mu \mathrm{m} \mathrm{TiO}{ }_{2}$ film were calculated as $0.034 \mu \mathrm{m}^{-1}$ at $600 \mathrm{~nm}$ and $0.288 \mu \mathrm{m}^{-1}$ at $500 \mathrm{~nm}$. The absorbance of a $\mathrm{TiO}_{2}$ film was calculated from the difference of a dye adsorbed $\mathrm{TiO}_{2}$ film and a blank semitransparent $\mathrm{TiO}_{2}$ film. Therefore, the reflection part by $\mathrm{TiO}_{2}$ could be minimized, and the light-harvesting efficiency was estimated directly from the absorbance. ${ }^{29}$ As we presumed that the $\mathrm{TiO}_{2}$ film was uniform and the reflection part of incident light was small, the light-harvesting efficiency for the dye on a $14 \mu \mathrm{m} \mathrm{TiO}$ film was then estimated to be $38 \%$ at $600 \mathrm{~nm}$ and $98 \%$ at $500 \mathrm{~nm}$. This derivation is consistent with the IPCE values measured for the device of $1(27 \%$ at $600 \mathrm{~nm}$ and $70 \%$ at $500 \mathrm{~nm})$. The conversion photocurrent density can thus be estimated by integrating the product of the IPCE value at each wavelength and the photon flux density data listed in the AM 1.5 solar spectrum $\left(100 \mathrm{~mW} / \mathrm{cm}^{2}\right) .{ }^{30}$ Accordingly, it was calculated to be $\sim 10$ $\mathrm{mA} / \mathrm{cm}^{2}$ for the 1 -sensitized solar cell. This value is smaller than that $\left(14.5 \mathrm{~mA} / \mathrm{cm}^{2}\right)$ measured from our AM 1.5 simulated light source. It is important to note that the photocurrent density measured is slightly overestimated due to the nonmask device. Another factor for the discrepancy may be attributed to the filtration of infrared radiation by a water filter in our light source during measurement, while the real sun spectrum ${ }^{30}$ covers the near-infrared portion. This mismatch in the spectra increases the ratio in the visible region and inflates the photocurrent.

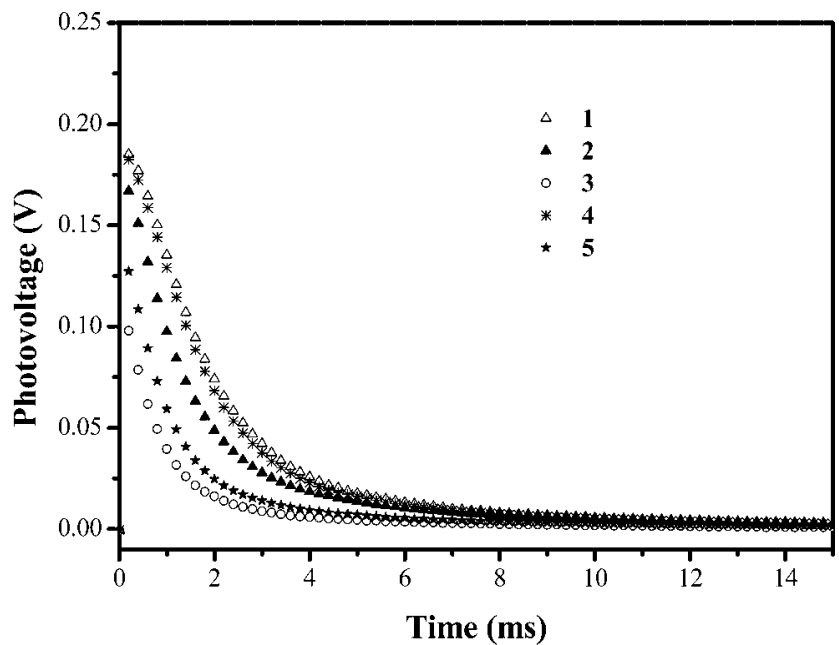

Figure 7. Transient photovoltages of $\mathbf{1 - 5}$ sensitized cells with $0.5 \mathrm{M} \mathrm{LiI}$ in $\mathrm{CH}_{3} \mathrm{CN}$ solution.
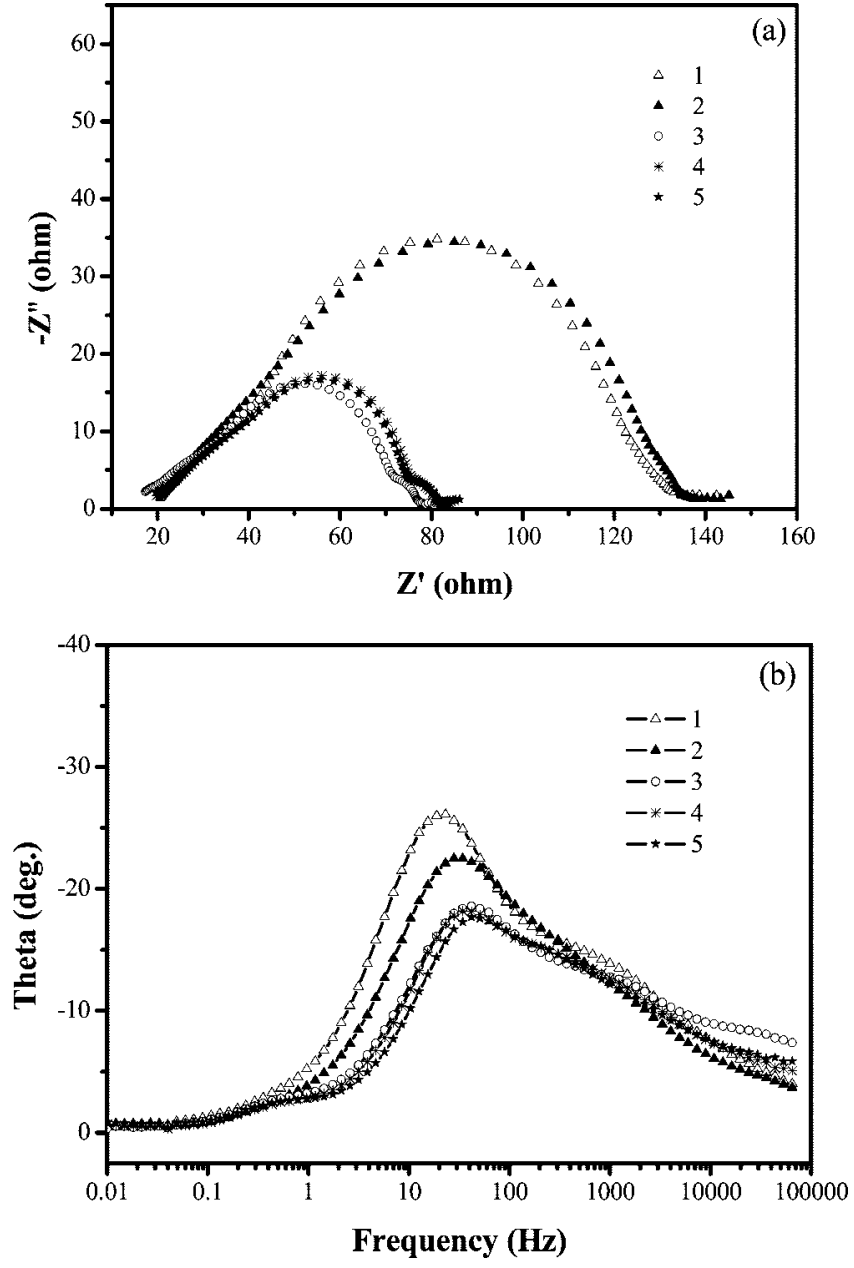

Figure 8. (a) Electrochemical impedance spectra of DSSC for dyes measured in the dark under $-0.65 \mathrm{~V}$ bias: (a) Nyquist plots, (b) Bode phase plots.

Table 3. Calculated Energy Level of the $S_{1}$ Transition for Compounds 2 and 5

\begin{tabular}{ccccc}
\hline dye & \multicolumn{1}{c}{ excitation } & $\lambda_{\text {cal }}(\mathrm{nm})$ & $f^{a}$ & $\begin{array}{c}\text { charge transfer } \\
\text { efficiency }\end{array}$ \\
\hline 2 & HOMO $\rightarrow$ LUMO $(+43 \%)$ & 472.2 & 1.0 & $35.9 \%$ \\
& HOMO-2 $\rightarrow$ LUMO $(32 \%)$ & & & \\
& HOMO $\rightarrow$ LUMO+1 $(+10 \%)$ & & & $28.4 \%$ \\
5 & HOMO $\rightarrow$ LUMO $(+60 \%)$ & 499.0 & 1.0 & \\
& HOMO $\rightarrow$ LUMO+1 $(15 \%)$ & & & \\
& HOMO-1 $\rightarrow$ LUMO $(14 \%)$ & & & \\
${ }^{a}$ Oscillator strength.
\end{tabular}

To support the above viewpoints, the recombination lifetime of the photoinjected electron with the oxidized dye was measured by transient photovoltage ${ }^{31}$ at open circuit (Figure 7). The electrolyte used in these studies was $0.5 \mathrm{M}$ of $\mathrm{LiClO}_{4}$ or $\mathrm{LiI}$ in $\mathrm{CH}_{3} \mathrm{CN}$. Note that $\mathrm{I}_{2}$ was not present in the electrolyte to avoid the possibility of dark current. The resulting $\tau_{\mathrm{R}}$ values for the devices of $\mathbf{1}, \mathbf{2}, \mathbf{3}, \mathbf{4}, \mathbf{5}$, and $\mathrm{N} 3$ were $0.04,0.04,0.01,0.01,0.04$, and $0.47 \mathrm{~ms}$, respectively, using $\mathrm{LiClO}_{4}$ as the electrolyte. When LiI electrolyte was used, retardation of the recombination was evident, and the

(29) Wang, Z.-S.; Cui, Y.; Hara, K.; Dan-oh, Y.; Kasada, C.; Shinpo, A. Adv. Mater. 2007, 19, 1138.

(30) Annual Book of ASTM Standards, ASTM International: West Conshohocken, PA, 2003, Vol. 14.04, pp G159-98.

(31) Kopidakis, N.; Benkstein, K. D.; van de Lagemaat, J.; Frank, A. J. J. Phys. Chem. B 2003, 107, 11307. 


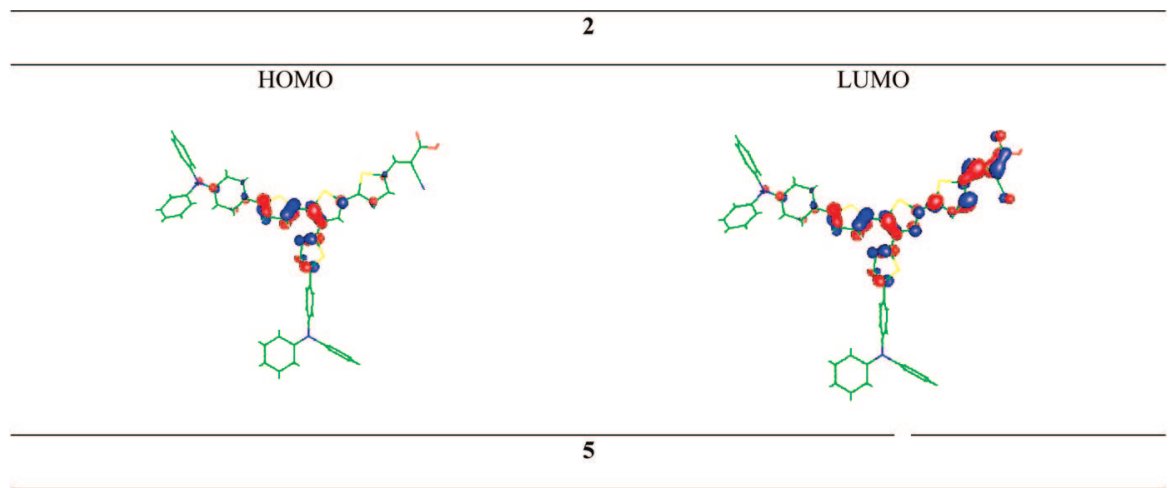

HOMO

LUMO
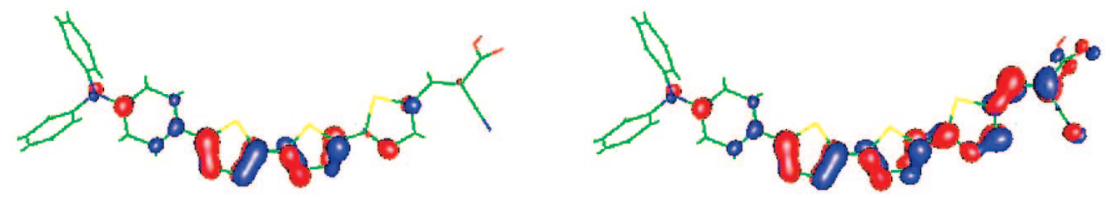

Figure 9. Selected frontier orbitals of $\mathbf{2}$ and 5. Note that only representative HOMO and LUMO are depicted here.

$\tau_{\mathrm{R}}$ values for the devices of $\mathbf{1}, \mathbf{2}, \mathbf{3}, \mathbf{4}, \mathbf{5}$, and $\mathrm{N} 3$ were measured to be $1.94,1.85,1.02,1.84,1.19$, and $2.23 \mathrm{~ms}$, respectively. The longer lifetimes for $\mathbf{1 , 2}, \mathbf{4}$, and N3 are in accordance with the device efficiency.

Electrochemical impedance was also measured in the dark to elucidate correlation of $\mathrm{V}_{\mathrm{OC}}$ with dyes. In these cells, the electrons are transported through the mesoscopic $\mathrm{TiO}_{2}$ network and react with $\mathrm{I}_{3}{ }^{-}$. At the same time, $\mathrm{I}^{-}$is oxidized to $\mathrm{I}_{3}{ }^{-}$at the counter electrode. The net current can be largely dependent on the applied bias. The Nyquist plots of DSSCs with different dyes under a forward bias of $-0.65 \mathrm{~V}$ are shown in Figure 8a. The Bode phase plots are also shown in Figure 8b. Three semicircles were observed in the Nyquist plots. The smaller semicircle at high frequencies $\left(>1 \times 10^{2}\right.$ $\mathrm{Hz}$ ) is assigned to the redox charge transfer response at the Pt/electrolyte interface. The larger one at intermediated frequencies $\left(1-10^{2} \mathrm{~Hz}\right)$ represents the electron transfer impedance at the $\mathrm{TiO}_{2} /$ dye/electrolyte interface and the last one at low frequencies $(<1 \mathrm{~Hz})$ shows the Nernst diffusion response of the electrolyte. ${ }^{32}$ The charge recombination resistance at the $\mathrm{TiO}_{2}$ surface, $R_{\mathrm{rec}}$, can be deduced by fitting curves from the range of intermediated frequency using a $\mathrm{Z}$-view software. The charge recombination resistance is related to the charge recombination rate, such that a smaller $R_{\text {rec }}$ means the larger charge recombination rate. The $R_{\text {rec }}$ values for 1 and 2 were estimated to be 87 and $90 \mathrm{ohm}$, respectively. In contrast, $\mathbf{3}, \mathbf{4}$, and $\mathbf{5}$ were found to have relatively smaller $R_{\text {rec }}$ values at 37, 42, and $40 \mathrm{ohm}$, respectively. The result appears to be consistent with the larger $\mathrm{V}_{\mathrm{OC}}$ values in the devices of $\mathbf{1}$ and $\mathbf{2}$. he significantly increased $R_{\text {rec }}$ values in the devices of $\mathbf{1}$ and $\mathbf{2}$ imply the retardation of the charge recombination between injected electron and electron acceptor $\left(\mathrm{I}_{3}{ }^{-}\right)$in the electrolyte, with

(32) (a) van de Lagemaat, J.; Park, N.-G.; Frank, A. J. J. Phys. Chem. B 2000, 104, 2044. (b) Kern, R.; Sastrawan, R.; Ferber, L.; Stangl, R.; Luther, J. Electrochim. Acta 2002, 47, 4213. (c) Wang, Q.; Moser, J.-E.; Grätzel, M. J. Phys. Chem. B 2005, 109, 14945. (d) Kuang, D.; Ito, S.; Wenger, B.; Klein, C.; Moser, J. E.; Humphry-Baker, R.; Zakeeruddin, S. M.; Grätzel, M. J. Am. Chem. Soc. 2006, 128, 4146. a consequent increase of $\mathrm{V}_{\mathrm{OC}}$. Correspondingly, the frequency of the characteristic peak $\left(1-1 \times 10^{2} \mathrm{~Hz}\right)$ in the Bode plots is smaller for $\mathbf{1}$ and $\mathbf{2}$, suggesting that devices of $\mathbf{1}$ and $\mathbf{2}$ have longer electron lifetimes ${ }^{32 c}$ due to slower recapture of the conduction band electrons by $\mathrm{I}_{3}{ }^{-}$. This outcome is consistent with our previous argument that incorporation of the hydrophobic 3-arylamine segments in $\mathbf{1}$ and $\mathbf{2}$ decreases the probability of electron capture by $\mathrm{I}_{3}{ }^{-}$.

Theoretical Approach. To provide further insight into the fundamental basis of the titled dyes, Table 3 and Figure 9 show the results of theoretical approaches (See Experimental Section) for the prototypical compounds 2 and $\mathbf{5}$. Apparently, the coplanarity between the donor and acceptor moieties in $\mathbf{5}$ is distinct, as represented by the $\angle \mathrm{S}_{1}-\mathrm{C}_{1}-\mathrm{C}_{2}-\mathrm{S}_{2} \approx 9.3^{\circ}$ of the dihedral angle. (see Figure 1 for the atom label). Conversely, due to the large steric effect introduced by dual diphenyl amino arms, 2 reveals a twisted conformation, e.g. $\angle \mathrm{S}_{1}-\mathrm{C}_{1}-\mathrm{C}_{2}-\mathrm{S}_{2} \approx 59.6^{\circ}, \angle \mathrm{C}_{4}-\mathrm{C}_{3}-\mathrm{C}_{5}-\mathrm{C}_{6}$ $\approx 52.8^{\circ}$, (see Figure 1 for the atom label), which may perturb the conjugation efficiency of the chromophore and hence shorten the calculated excitation wavelength (see Table 3), the result of which is qualitatively consistent with the experimental observation (vide supra). Compared with photophysical data obtained experimentally, the deviation of the current theoretical approach from the experimental results may be due in part to the lack of the solvent polarity effect, which normally leads to a further spectral shift. Nevertheless, the result qualitatively predicts the tendencies of the relative energy levels of these compounds, supporting the validity of the currently adopted calculation method and its level.

Moreover, as depicted in Table 3 and Figure 9, for both 2 and $\mathbf{5}$, the $S_{1}$ state mainly consists of mixed transitions, in which the delocalization of electron density from diphenyl amino to carboxylic groups is apparent. This, in combination with the near unity oscillator strength $(f)$, confirms the charge transfer $\left(\pi-\pi^{*}\right)$ type of transition in the first excited state, supporting the aforementioned experimental results. Also, the efficiency of charge transfer in the $S_{1}$ state was calculated 
via the difference of charge density in the acceptor moiety between the involved occupied and unoccupied orbitals. As listed in Table 3, 2 reveals a larger charge transfer efficiency than $\mathbf{5}(\mathbf{2}, 35.9 \% ; \mathbf{5}, 28.4 \%)$. Because the electron injection to $\mathrm{TiO}_{2}$ is through the binding between $\mathrm{TiO}_{2}$ and acceptor moiety, the results rationalize the superior DSSC efficiency for 2 .

\section{Conclusions}

In summary, we have synthesized a new class of dyes featuring oligothiophene conjugation, diarylamines as electron donors at the 2- and 3-sites, and 2-cyanoacrylic acids as electron acceptors. Despite the shorter wavelength absorption, the performance achieved for the DSSCs constructed from this new series dyes is of significance. Incorporation of a hydrophobic arylamine-containing segment at the 3-position of the thiophene spacer was demonstrated to be beneficial for retarding the electron transfer from $\mathrm{TiO}_{2}$ to the oxidized dye or electrolyte and to enhance the charge transfer efficiency in the excited state. The devices in this study appear to have efficiencies comparable to those of the oligothiophene-based sensitizer. ${ }^{12 \mathrm{~g}}$ It thus is likely that incorporation of appropriate alkyl chains in the thiophene rings will further improve the performance of the cells. Work focusing on extending this strategy to synthesize a variety of spirobifluorene-based dyes is currently in progress.

Acknowledgment. We thank the Research Centre for Applied Sciences, Academia Sinica (RCAS), National Taiwan University, and the National Science Council for supporting this work.

CM702631R 